\title{
Distribution, habitat suitability, conservation state and natural history of endangered salamander Bolitoglossa pandi
}

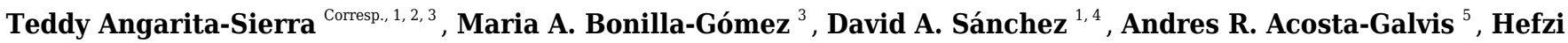 \\ Medina-Ovalle $^{3}$, Anggi Solano-Moreno ${ }^{3}$, Simon Ulloa-Rengifo ${ }^{3}$, Daniela Guevara-Guevara ${ }^{3}$, Juan J. Torres-Ramirez \\ ${ }^{3}$, Sebastián Curaca-Fierro ${ }^{3}$, Diego M. Cabrera-Amaya ${ }^{1}$, Jhon A. Infante-Betancour ${ }^{1}$, Luisa F. Londoño-Montaño ${ }^{1}$, \\ Diana X. Albarán-Montoya ${ }^{6}$, Lesly R. Peña-Baez ${ }^{6}$ \\ 1 YOLUKA ONG, Fundación de investigación en Biodiversidad y Conservación, Bogotá, Colombia \\ 2 Vicerectoria de investigación, Universidad Manuela Beltrán, Bogotá, Colombia \\ 3 Grupo de Investigación de Biología de Organismos Tropicales (BIOTUN), Departamento de biología, Universidad Nacional de Colombia, Bogotá, Colombia \\ 4 Instituto Amazónico de Investigaciones Científicas SINCHI, Leticia, Amazonas, Colombia \\ 5 Colecciones Biológicas IAvH, Subdirección de Investigaciones, Instituto de Investigación de Recursos Biológicos Alexander von Humboldt, Villa de Leyva, \\ Boyacá, Colombia \\ 6 Fundación Ecotrópico Colombia, Bogotá, Colombia \\ Corresponding Author: Teddy Angarita-Sierra \\ Email address: tgangaritas@unal.edu.co
}

Background. Pandi's mushroom-tongue salamander (Bolitoglossa pandi) is one of the threatened amphibians in South America, as well as a flagship species for the Colombian conservation agenda. This species is endemic to the Andean cloud forests of the western slope of the Cordillera Oriental of Colombia, occurring only in the department of Cundinamarca within a narrow elevational range. At night, $B$. pandi can be seen perching on the upper side of leaves at heights ranging from ground level to $2.5 \mathrm{~m}$. During the day, it can be found under leaf litter or cover objects. Few studies have provided relevant information that can help the Colombian government to formulate lines of action for the conservation of this species; consequently, its threat assessments so far have been based on very limited information .

Methods. We conducted surveys for salamanders in four municipalities of Cundinamarca, Colombia, using two approaches: visual encounter surveys (Guaduas and Villeta) and the basic sampling protocol for single-species occupancy modeling (Supatá and Venecia). Multivariate analyses were employed to explore the correlation between habitat structure and natural history traits, abundance, and detection / non-detection of $B$. pandi. We evaluated the $B$. pandi activity pattern through kernel density curves for each sampling occasion and explored the variability of salamander abundance during their activity period by performing a nested ANOVA.

Results. We report the discovery of two new populations of $B$. pandi, which represent the most northwestern records known. A significant correlation between body length, body mass, and habitat structure was observed. Multivariate analyses indicated that leaf litter depth, mean temperature, percent vegetation cover, and altitude were the habitat variables that together explained $60.3 \%$ of the $B$. pandi abundance variability, as well as the main determinants of its optimal habitat. Bolitoglossa pandi exhibits an activity pattern characterized by two main activity peaks, in which niche time-partitioning was observed. Across the surveyed area, we found a healthy, stable, highly dense population of $B$. pandi (>1300 individuals), with seasonal variability between development stages .

Discussion. Given the high habitat specificity of $B$. pandi, the species is highly vulnerable to local changes. Thus, we recommend that $B$. pandi be retained as Endangered (EN) on the IUCN Red List, based Peer] reviewing PDF | (2020:04:47555:2:0:NEW 29 Jul 2020) 
on the IUCN Criterion B, given its restricted extent of occurrence (ca. 2,500 $\mathrm{km}^{2}$ ) and the ongoing threats from agriculture, cattle ranching, logging, and urban development, which continue to reduce its suitable habitat . 
1 Distribution, habitat suitability, conservation state and natural history of the

2 endangered salamander Bolitoglossa pandi

3

4 Teddy Angarita-Sierra ${ }^{1,2,3^{*}}$, María A. Bonilla-Gómez ${ }^{3}$, David A. Sánchez ${ }^{1,6}$, Andrés R.

5 Acosta-Galvis ${ }^{4}$, Hefzi Medina-Ovalle ${ }^{3}$, Anggi Solano-Moreno ${ }^{3}$, Simon Ulloa-Rengifo ${ }^{3}$,

6 Daniela Guevara-Guevara ${ }^{3}$, Juan J. Torres-Ramirez ${ }^{3}$, Sebastián Curaca-Fierro ${ }^{3}$, Diego

7 M. Cabrera-Amaya ${ }^{1}$, Jhon A. Infante-Betancour ${ }^{1}$, Luisa F. Montaño-Londoño ${ }^{1}$, Diana X.

8 Albarán-Montoya, ${ }^{5}$ and Lesly R. Peña-Baez. ${ }^{5}$

1 YOLUKA ONG, Fundación de Investigación en Biodiversidad y Conservación Bogotá, 11 Colombia.

$12{ }^{2}$ Vicerrectoría de Investigación, Universidad Manuela Beltrán, Bogotá, Colombia.

$13{ }^{3}$ Grupo de Investigación de Biología de Organismos Tropicales (BIOTUN),

14 Departamento de Biología, Universidad Nacional de Colombia, Bogotá-Colombia.

${ }^{4}$ Colecciones Biológicas IAvH, Subdirección de Investigaciones, Instituto de

Investigación de Recursos Biológicos Alexander von Humboldt, Villa de Leyva, Boyacá, Colombia.

18 5.Fundación Ecotrópico Colombia, Bogotá, Colombia.

${ }^{6}$ Instituto Amazónico de Investigaciones Científicas SINCHI, Letica, Amazonas, Colombia.

Corresponding author:

24 Teddy Angarita-Sierra. ${ }^{1}$

25 Carrera 68B \# 23-88, Bogotá, Colombia, Zip code: 110931.

26 Email address: tgangaritas@unal.edu.co 
28

29

30

31

32

33

34

35

36

37

38

39

40

41

42

43

44

45

46

47

48

49

50

51

52

53

54

55

56

57

58

59

60

61

62

63

\section{Abstract}

Background. Pandi's mushroom-tongue salamander (Bolitoglossa pandi) is one of the threatened amphibians in South America, as well as a flagship species for the Colombian conservation agenda. This species is endemic to the Andean cloud forests of the western slope of the Cordillera Oriental of Colombia, occurring only in the department of Cundinamarca within a narrow elevational range. At night, $B$. pandi can be seen perching on the upper side of leaves at heights ranging from ground level to 2.5 $m$. During the day, it can be found under leaf litter or cover objects. Few studies have provided relevant information that can help the Colombian government to formulate lines of action for the conservation of this species; consequently, its threat assessments so far have been based on very limited information.

Methods. We conducted surveys for salamanders in four municipalities of Cundinamarca, Colombia, using two approaches: visual encounter surveys (Guaduas and Villeta) and the basic sampling protocol for single-species occupancy modeling (Supatá and Venecia). Multivariate analyses were employed to explore the correlation between habitat structure and natural history traits, abundance, and detection / nondetection of $B$. pandi. We evaluated the $B$. pandi activity pattern through kernel density curves for each sampling occasion and explored the variability of salamander abundance during their activity period by performing a nested ANOVA.

Results. We report the discovery of two new populations of $B$. pandi, which represent the most northwestern records known. A significant correlation between body length, body mass, and habitat structure was observed. Multivariate analyses indicated that leaf litter depth, mean temperature, percent vegetation cover, and altitude were the habitat variables that together explained $60.3 \%$ of the $B$. pandi abundance variability, as well as the main determinants of its optimal habitat. Bolitoglossa pandi exhibits an activity pattern characterized by two main activity peaks, in which niche time-partitioning was observed. Across the surveyed area, we found a healthy, stable, highly dense population of $B$. pandi (>1300 individuals), with seasonal variability between development stages.

Discussion. Given the high habitat specificity of $B$. pandi, the species is highly vulnerable to local changes. Thus, we recommend that $B$. pandi be retained as Endangered (EN) on the IUCN Red List, based on the IUCN Criterion B, given its restricted extent of occurrence (ca. 2,500 $\mathrm{km}^{2}$ ) and the ongoing threats from agriculture, cattle ranching, logging, and urban development, which continue to reduce its suitable habitat. 
64

65

66

67

68

69

70

71

72

73

74

75

76

77

78

79

80

81

82

83

84

85

86

87

88

89

90

91

92

93

94

95

96

97

98

99

100

101

102

103

\section{Introduction}

Colombia is home to more than 850 species of amphibians, being mainly concentrated in the Andean Forest (Acosta-Galvis, 2020). Geographic distributions of fauna in this biome are often restricted and endemism is common (Lynch \& Suárez-Mayorga, 2002). Andean forests are among the most threatened habitats in the country due to the drastic transformation of native vegetation by urban growth, mining, agriculture, and cattle ranching (Etter et al., 2018). As a consequence and given that most threatened Colombian amphibian species are concentrated between 1800-3600 m a.s.l., habitat loss is the main threat shared by most species.

Among threatened Colombian amphibians, salamanders of the genus Bolitoglossa are one of the flagship amphibian groups on the Colombian conservation agenda. This genus is the most diverse and geographically widespread lineage of plethodontid salamanders inhabiting the Western Hemisphere. Currently, Bolitoglossa comprises 134 species, 24 of which reside in Colombia across several types of tropical habitats (Wake, 2017; Acosta-Galvis, 2020; Frost, 2020). Many species of Bolitoglossa exhibit restricted geographic ranges [e.g. Bolitoglossa capitana (Brame \& Wake, 1963), B. hypacra (Brame \& Wake, 1962), B. hiemalis (Lynch, 2001), among others]. However, the high level of morphological crypsis and an incomplete understanding of the morphological variability among Andean Bolitoglossa species make suitable determinations regarding their distributional ranges hard to achieve (Acosta-Galvis \& Gutiérrez-Lamus, 2012).

The ecology and life history of South American Bolitoglossa salamanders are poorly understood compared to their Central and North American congeners; less than $12 \%$ of South American Bolitoglossa species have been investigated with published information on their diet, reproduction, foraging activities, thermal ecology, demography, ecological interactions, microhabitat use, or habitat preferences (Houck, 1977; Jimenez, 1994; Bruce, 1997; Salgado-Aráuz, 2005; Anderson \& Mathis, 2006; Cadenas et al., 2009; Ortega, Monares-Riaño \& Ramírez-Pinilla, 2009; Neckel-Oliveira et al., 2011; del Río-Gracía, Serrano-Cardozo \& Ramírez-Pinilla, 2014; Cruz, Galindo \& Bernal, 2016). Given this dearth of information, the conservation status of many of these species is Data Deficient (DD) or has been based on limited information.

According to the IUCN red list of threatened species, Bolitoglossa pandi (Brame \& Wake, 1963) is Endangered B1ab (iii), based on its restricted geographical range. It was originally described based on a single specimen (holotype ZSZMH 2858, an adult female with Snout-vent length $50.4 \mathrm{~mm}$, collected in 1913 by Wilhelm Frietsche) from the municipality of Pandi, Cundinamarca (exact locality within the municipality is unknown), in the cloud forests on the western slope of the Cordillera Oriental of Colombia. Subsequently, Hanken and Wake (1982) reported a second specimen $75 \mathrm{~km}$ north airline from the type locality, in a bromeliad inside primary cloud forest, near the municipality of Albán (Cundinamarca), at 2400 m a.s.l. 
104

Acosta-Galvis and Rueda-Almonacid (2004) reported a third specimen (an adult female with snout-vent length (SVL) $44.7 \mathrm{~mm}$, collected by Franz Kaston, ICN 45500) near the municipality of Pandi and described the associated habitat as relict wet areas covered by lush trees and shrubs. Acosta-Galvis and Gutiérrez-Lamus, (2012) included a new record for the Supatá region (adult male with SVL $37.63 \mathrm{~mm}$, MUJ 7921) representing the northernmost record of the species. Hence, the known distribution of $B$. pandi includes four localities from the sub-Andean forests between 1300-2400 m a.s.l., throughout the western slopes of the Cordillera Oriental. Since its first extinction risk assessment was performed 14 years ago, few studies have provided relevant information for the formulation of strategies or an action plan for its conservation (del Río-García, Serrano-Cardozo, \& Ramírez-Pinilla, 2014).

The aims in this study are: (1) to describe the geographic range of $B$. pandi along the western slopes of the Cordillera Oriental; (2) to explore the relationship between habitat structure and natural history traits of this species; (3) to describe its activity pattern and population stage-structure; (4) to expand the knowledge of the variability of certain morphological characters and life-history traits of this poorly known species; (5) and to provide a conservation status reassessment of $B$. pandi.

\section{Materials \& Methods}

\section{Ethics statement}

Sex was not determined on living salamanders due to the high risk of injury to the animal. Fieldwork was done under the scientific research non-commercial purpose permit of collection of wild specimens of biological diversity issued by the National University of Colombia (Research Project 38615), and the Colombian National Environmental Licensing Authority (ANLA) by resolution No. 0255 of 14 March 2014. This study was conducted following the Colombian animal welfare law and the collection of wild specimens of the biological diversity acts (Ley 1774, 2016; Decreto 1376, 2013), as well as considering the Universal Declaration on Animal Welfare (UDAW) endorsed by Colombia in 2007.

\section{Study area}

We searched for salamanders at nine localities in four municipalities of Cundinamarca located on the western slope of the Cordillera Oriental of Colombia: Guaduas, Supatá, Venecia and Villeta (Fig. 1). Searches at each locality were carried out within an elevational gradient ranging from 1638 to $2315 \mathrm{~m}$ a.s.l (Table 1). The sampled area includes sub-Andean and Andean forests, as well as areas transformed by urban growth, agriculture, and cattle ranching. The sampling area is characterized by a bimodal climate [high dry season (from mid-December to mid-March); high rainy season (from mid-March through June); low dry season (from July to mid-September), low rainy season (from mid-September to mid-December)]. We monitored the environmental 
144 temperature $(\mathrm{ET})$ and relative humidity $(\mathrm{RH})$ at sampling sites using Ebro $\circledast$ thermo145 hygrometers (model EBI 20-TH1).

\section{Sampling and data collection}

We conducted surveys for salamanders using two approaches. First, during the rainy season in April-May 2013, we performed visual encounter surveys (VES; Crump \& Scott, 1994) in three localities associated with cloud forests throughout an altitudinal gradient (1648-2002 $\mathrm{m}$ a.s.l) in the municipalities of Guaduas and Villeta (Table 1). Two researchers surveyed day and night for five days, for a total of $100 \mathrm{~h}$ of sampling effort.

Second, we employed the basic sampling protocol described by Mackenzie et al., (2003) for single-species occupancy modeling in six localities, three in the municipality of Supatá and three in Venecia. We randomly selected a total of 296 plots $(5 \mathrm{~m} \times 5 \mathrm{~m})$, which were located throughout an altitudinal gradient at each sampling locality (1600$2300 \mathrm{~m}$ a.s.l), grouping the following vegetation covers: Andean forest fragments, restored Andean riparian forest, pastures and roadsides (Table 1). During three sampling occasions (September-October 2017, March 2018, and July 2018), each plot was surveyed day and night for five consecutive days by ten researchers, resulting in a total of $2100 \mathrm{~h}$ of sampling effort. During each survey, the detection / non-detection of $B$. pandi specimens were recorded. When a salamander was present, we measured its perch height using a measuring tape $( \pm 0.1 \mathrm{~cm})$. Once salamanders were caught, we recorded their weight with a Pesola $₫$ dynamometer of $50 \mathrm{~g}( \pm 0.1 \mathrm{~g})$ and took photographs to measure their body size [SVL = snout-vent length $(\mathrm{mm}), \mathrm{TL}=$ Tail length $(\mathrm{mm})]$ using the software Image-J v. 1.52 (Bourne, 2010). All specimens of $B$. pandi were subsequently released near the quadrat where they were sighted.

Based on 18 specimens collected, euthanized using $2 \%$ lidocaine, and fixed in $10 \%$ formalin (Chen \& Combs, 2001), we described the morphological variability of $B$. pandi. We made a small incision in the groin region to identify their sex and sexual maturity through macroscopic observation of the gonads. All the morphological terminology employed follows several contributions (Brame \& Wake, 1962, Brame \& Wake, 1963; Acosta-Galvis \& Restrepo, 2001; Lynch, 2001; Acosta-Galvis \& Hoyos, 2006; Acosta-Galvis \& Gutierrez-Lamus, 2012; Brcko, Hoogmoed \& Neckel-Oliveira, 2013; Bingham et al., 2018). All specimens were deposited in the amphibian collection at Instituto de Investigación de Recursos Biológicos Alexander von Humboldt, (IAvHAm), as well as in the amphibian collection at the Instituto de Ciencias Naturales de la Universidad Nacional de Colombia (ICN).

\section{Habitat structure data collection}

We used the Point Intercept Method described by Elzinga, Salzer, \& Willoughby (1998) to estimate the percent vegetation cover. We grouped plants into eight growth forms: graminoids, forbs, palm trees, mosses, lichens, vines, shrubs, and trees. We divided 
184 vegetation into layers: $0-0.1 \mathrm{~m}, 0.1-1 \mathrm{~m}, 1-1.5 \mathrm{~m}, 1.5-3 \mathrm{~m}, 3-5 \mathrm{~m}$, and 5-12 m. We 185 also considered ground characteristics such as leaf litter, bare soil and bare rocks. We 186 estimated the vegetation cover of each of the plots where salamanders were surveyed, 187 employing a set of 15 intercept points distributed in three parallel lines of five points 188 separated by one meter of distance. At each point, we used a sampling bar of $1.5 \mathrm{~m}$ to 189 register the contact of the growth forms of each vegetation layer below $1.5 \mathrm{~m}$. This 190 provided us with a $6.67 \%$ cover resolution by layer. We assessed the percentage cover of the vegetation layers above $1.5 \mathrm{~m}$ (mostly trees) using five intercept points: the corners of the quadrant and the central point of the third line. In this way, we reached a $20 \%$ cover resolution for upper layers.

194

195

196

197

198

199

200

201

202

203

204

205

206

207

208

209

210

211

212

213

214

215

216

217

218

219

220

221

222

\section{Statistical analysis}

We evaluated the association between habitat structure and the natural history traits of B. pandi by multiple correlation analysis, with $P<0.05$ as the significance level. The following variables were considered: SVL $(\mathrm{mm})$, weight $(\mathrm{g})$, perch height $(\mathrm{mm})$, leaf litter depth $(\mathrm{mm})$, vegetation layers, vegetation life form, percent vegetation cover and elevation (meters above sea level). Using the habitat variables, we performed a principal component analysis (PCA) to explore which of these variables presented greater variability between plots with regards the detection / non-detection of $B$. pandi and, therefore, which of these could explain the observed differences between plots. The variable suitability for PCA was tested performing a Kaiser-Meyer-Olkin test (KMO $>0.5, \mathrm{P}<0.05$ ). Afterward, a quadratic discriminant analysis was performed to determine which of the habitat variables had the greatest discrimination capacity between plots where $B$. pandi was detected / non-detected.

We assessed the variability in salamander abundance observed in the Supatá population through multiple regression analysis. First, we considered the salamander abundance as a dependent variable and the habitat structure variables recorded at each sampling plot as independent variables: leaf litter depth $(\mathrm{mm})$, vegetation layers, vegetation growth forms, percent vegetation cover, elevation (meters above sea level), temperature $\left({ }^{\circ} \mathrm{C}\right)$ and environment relative humidity. All variables were $\mathrm{Ln}-$ transformed prior to perform the statistical analysis.

Second, we evaluated assumptions of normality, autocorrelation, and homoscedasticity using Kolmogorov-Smirnov test, Durbin-Watson test and BreuschPagan test, respectively. Given that the $p-$ value of the Durbin-Watson test can easily be less than 0.05 when sample size is very large, we used the Durbin-Watson statistic test (DW) as an autocorrelation criterion. According to Durbin \& Waston (1950), a DW of less than 1 indicates a strong positive autocorrelation, a DW greater than 4 indicates a strong negative autocorrelation, values between 1 and 3 suggest a moderate autocorrelation, and a value close to 2 means that there is no autocorrelation. 
224 Third, we tested for multicollinearity between the variables using the variance inflation

225

226

227

228

229

230

231

232

233

234

235

236

237

238

239

240

241

242

243

244

245

246

247

248

249

250

251

252

253

254

255

256

257

258

factor (VIF) with a threshold of 10. Fourth, we selected the "best" regression model employing the Akaike Information Criterion (AIC; Akaike, 1973), considering that models with $\triangle$ AIC values of less than two are equally plausible (White \& Burnham, 1999). Finally, we used the hierarchical partitioning method to evaluate the contribution of all the independent variables of the regression model (Chevan \& Sutherland, 1991).

\section{Activity pattern and population stage-structure}

We only assessed the activity pattern and the population stage-structure of the $B$. pandi population at the Cuzcungos locality given the high abundance observed (Table 1). We estimated the activity pattern through kernel density curves for each sampling occasion, as well as combining all sampling occasions. We explored the salamander abundance variability during their activity period by performing a nested ANOVA. Hence, the activity period of $B$. pandi was divided into nine time-intervals (from $\mathrm{H} 1=18: 30-19: 30, \mathrm{H} 2=$ 19:31-20:30, H3 $=\ldots$ until $\mathrm{H} 9=02: 31-03: 30$ ), and each salamander sighting was allocated into its respective interval. The sampling occasion was used as the primary factor, and the time intervals as the secondary factor nested in the primary factor. We evaluated assumptions of normality and homogeneity of variances using a Shapiro-Wilk test and Levene test, respectively. Additionally, we analyzed the variability in observed body size over the nine time-intervals through a non-parametric ANOVA using a Kruskal-Wallis test (KW) as a measure of the central tendency of the samples (Sokal \& Rohlf, 1981).

We used SVL as a descriptive variable of the population stage-structure of $B$. pandi. We compared the variability in population stage-structure among sampling occasions through a Wilcoxon test, with the null hypothesis being that population median stage-structure was the same across all sampling occasions. According to the categories proposed by Acosta-Galvis \& Gutierrez-Lamus (2012) and del Río-Gracía, Serrano-Cardozo \& Ramírez-Pinilla (2014), as well as the development stage of the collected salamanders, the population was divided into stage classes as follows: neonates $(\leq 23 \mathrm{~mm})$, juveniles $(24-30 \mathrm{~mm})$, and adults $(\geq 30 \mathrm{~mm})$.

All statistical analyses were performed using the software Rwizard 4.3 (Guisande et al., 2014) and the following R packages: car (Fox \& Weisberg, 2019), hier.part (Nally \& Walsh, 2004), lawstat (Hui, Gel, \& Gastwirth, 2008), nortest (Gross \& Ligges, 2015), overlap (Ridout \& Linkie, 2009) stat (Bolar, 2019) and usdm (Naimi et al., 2014). 
259 Results

260 Geographic distribution

261 We found a total of $34 \mathrm{~B}$. pandi individuals at three new localities, extending the

262 geographical range of the species by $96.5 \mathrm{Km}$ (airline) northwest from the type-locality, 263 and $33.6 \mathrm{~km}$ (airline) west from the northernmost locality in the municipality of Supatá

264 (Fig. 1). These new localities belong to the municipalities of Guaduas and Villeta in the 265 department of Cundinamarca. All the salamanders in the new localities were found at 266 night, within the understory of oak groves dominated by ferns. The salamanders were 267 found in different vertical strata ranging from leaf litter, where they remained hidden, to 268 shrubby substrates up to $2.5 \mathrm{~m}$. Additionally, two salamanders were found in ecotonal 269 areas associated with sugar cane crops and rangeland areas for livestock.

270

271

272

273

274

275

276

277

278

279

280

281

282

283

284

285

286

287

288

289

290

291

292

293

294

295

296

297

298

\section{Associations of habitat structure and natural history traits}

We observed a significant association between habitat structure and morphological traits. Snout-vent length, tail length, and mass were significantly associated with all the habitat structure variables assessed, but less so with the vegetation layers. SVL, TL, and mass showed a negative correlation with leaf litter and elevation (Table 2). In contrast, SVL and mass showed a positive correlation with perch height and percent vegetation cover (Table 2, Fig. 2).

Similarly, the habitat structure variables were significantly associated with the detection or non-detection of $B$. pandi throughout the sampling plots. The first two components of the PCA accounted for $62.4 \%$ of the variability observed. The habitat structure variability was clustered in two groups associated with the detection or nondetection of $B$. pandi (Fig. 3A). These groups were moderately overlapping in multivariate space, but they were differentiated by elevation, leaf litter depth, and percent vegetation cover. The presence of $B$. pandi was positively correlated with highly structured plots and with deep leaf litter (Table 3 ). The quadratic discriminant analysis confirms that the detection or non-detection of $B$. pandi depends on habitat variables. The cross-validation percentage was $92.6 \%$, indicating that the quadrants in which $B$. pandi was detected can be clearly distinguished by habitat variables such as vegetation layers, leaf litter depth and mean environmental temperature (Fig. 3B).

Results of the multiple regression analysis showed that leaf litter depth, mean environmental temperature, percent vegetation cover, and elevation were the variables that contributed the most to explaining the observed variability in the abundance of $B$. pandi $\left(\mathrm{r}^{2}=60.3 \%, \mathrm{P}<0.001\right)$. These habitat variables also composed the best fitted regression model (Table 4). However, this model showed a moderate autocorrelation $(\mathrm{DW}=1.10)$, which means that the variance explained by the habitat variables may be close to $60.3 \%$.

\section{Activity pattern}


299

300

301

302

303

304

305

306

307

308

309

310

311

312

313

314

315

316

317

318

319

320

321

322

323

324

325

326

327

328

329

330

331

332

333

334

335

336

337

338

Bolitoglossa pandi is completely nocturnal; its activity period extends throughout the night, from 18:30 $\mathrm{h}$ until 05:00 $\mathrm{h}$. The environmental temperature recorded during this activity period ranged from $12.6-25.6^{\circ} \mathrm{C}(\mathrm{X}=15.3)$, and relative humidity ranged from $73.8-98.8(X=80.3)$. The activity peaks were all subject to environmental influences showing a significant association with the local weather conditions. The observed salamander abundance was strongly and positively correlated with the environmental temperature $\left(R_{E T}=0.251, P<0.001\right)$, whereas it was moderately and negatively correlated with relative humidity $\left(R_{R H}=-0.174 ; P=0.017\right)$. Across sampling occasions, we observed two consistent activity peaks, the first from 20:30 h to 21:30 h, and the second from 23:30 h to 00:30 h (Fig. 4A). Results of the nested ANOVA indicated that salamander abundance between these peaks was significantly different $\left(\mathrm{F}_{9-259}=4.57, \mathrm{P}\right.$ $<0.001$; Fig. 5A,Table 5), being higher in the second activity peak during the second and third sampling occasions, with the opposite pattern during the first sampling occasion (Fig. 4B-D).

Likewise, the observed body length of the salamanders showed significant differences between the two activity peaks ( $K_{8 d f}=99.70, P<0.001$, Fig. 5B), suggesting niche timepartitioning between body size classes. Most of the salamanders observed during the first activity peak had SVL $>30 \mathrm{~mm}$ (adults), whereas all the salamanders observed at the second activity peak had SVL $<27 \mathrm{~mm}$ (juveniles and neonates). However, in contrast to the differences in observed abundance between activity peaks, the variation in salamander SVL was between peaks was consistent across the three sampling occasions.

\section{Population stage-structure}

A total of 1391 individuals of $B$. pandi were observed throughout the study in the Supatá population, exhibiting a population density ranging from $0.04-1.44$ individuals $/ \mathrm{m}^{2}$. The population stage-structure showed significant differences between sampling occasions, suggesting seasonal variability between development stages (Table 6). Regardless of the variability observed in the population stage-structure of $B$. pandi, the population is mostly dominated by juveniles and neonates which represent between $34-64 \%$ of individuals (Fig. 6). Neonates were observed across all sampling occasions, indicating constant recruitment. During the second sampling occasion, a bias in the median SVL towards smaller individuals was observed, suggesting that the major recruitment peak occurs during March when the high rainy season start (Fig 6B). However, no samples were available between October to mid-December when the low rainy season occurs, thus, a second recruitment peak could be possible observed during this period. On the contrary, adults were conspicuous throughout all sampling occasions, especially so in the first sampling occasion.

\section{Morphological variability and comparisons to other species}


339

340

341

342

343

344

345

346

347

348

349

350

351

352

353

354

355

356

357

358

359

360

361

362

363

364

365

366

367

368

369

370

371

372

373

374

375

376

377

378

Bolitoglossa pandi is a small species, with SVL $=13.4-51 \mathrm{~mm}(\mathrm{~N}=1034), 34.4-48 \mathrm{~mm}$ adult males $(n=7)$, and SVL $36.6-51 \mathrm{~mm}$ adult females $(\mathrm{N}=8)$. Extensively webbed hands and feet with third toes and triangular digits; ventral surfaces of digit tips without terminal flattened tubercles; snout short and rounded in the lateral profile; head length 4.9-10.1 mm; head width 5.1-7.9 ( $\mathrm{N}=17)$; snout rounded in dorsal view, irregular white spots, cream-colored nasolabial grooves, and edges of the lips irregularly dark brown with irregular light spotting (Fig. 7A-B); protruding eyes on dorsal view, brown iris with black reticules (Fig. 7B); well-defined post-cephalic constriction; ventral surfaces (preserved) brown or dark grey with numerous tiny cream guanophores (Fig. 7CD);inverted bracket shaped scapular spots (Fig. 7J); males have white testes.

Bolitoglossa pandi can be distinguished from its Colombian congeners by the extensive webbing of its hands and feet (versus webbing of hands and feet reduced in B. adspersa, B. hiemalis, B. hypacra, B. palmata, B. ramosi, B. savagei, B. tamaense, B. tatamae, $B$. walkeri and $B$. vallecula). Furthermore, it can be distinguished from species with extensive webbing (such as Bolitoglossa lozanoi and $B$. nicefori) by having more protruding eyes, and a longer and triangular third digit. Bolitoglossa pandi also differs from $B$. biseriata and $B$. silverstonei by having a dark brown or dark grey ventral surface with irregular white dots (versus cream ventral surface with brown suffusions and dots in $B$. biseriata and $B$. silverstonei), brown-reddish iris with black reticles (versus golden with brown dots in $B$. biseriata and $B$. silverstonei), and white testes in adult males (versus black mesorchium in testes of adult males of $B$. biseriata). It also differs from $B$. medemi by the absence of digital depressions in the tips on the digits and toes (present in B. medemi). B. pandi also presents an upper lip with irregular light spotting (versus uniform in $B$. guaneae). $B$. pandi can be differentiated from $B$. altamazonica and $B$. leandrae by having extensive interdigital webbing with a longer and triangular third digit (complete webbing and tips rounded in $B$. altamazonica and $B$. leandrae). $B$. pandi is morphologically very similar to $B$. phalarosoma, but it differs by having a dark brown or dark grey ventral surface with diffuse white dots and some white blotches (versus usually light brown ventral surfaces, with some irregular cream spots in B. phalarosoma), plantar and palmar regions in ventral dark brown or dark grey view (versus cream in B. phalarosoma). B. pandi also differs from B. capitana by having smaller adult size with a longer and triangular third digit (versus rounded third digit in $B$. capitana) and shorter head.

\section{Color variability}

Bolitoglossa pandi exhibits a wide variation in color, ranging from a uniform dorsal color pattern of different shades of light to dark brown(Fig. 7E); one reddish-brown pattern that can have diffuse grey or scarcely distinguishable dark blotches that extend to the dorsolateral region (Fig. 7F), or an ochre pattern, with some diffuse irregular dark brown, yellow or cream spots (Fig. $7 \mathrm{G}-\mathrm{I}$ ). Some specimens exhibit a very diffuse band 
379 in the paravertebral region covering almost the entire dorsal surface or including a dark 380 brown inverted triangle shape in the interorbital region (Fig. $7 \mathrm{~J}-\mathrm{K}$ ). The caudal region is 381 highly variable, ranging from uniform reddish-brown or completely ochre segments, with 382 very small scattered white dots (Fig. 7D-F) to irregular cream, yellow or orange patches 383 (Fig. 7I), and very small or irregular longitudinal black spots (Fig. 7I-K). The distal end 384 of the tail becomes uniform light brown and has cream blotches towards the proximal 385 region in some individuals (Fig. $7 \mathrm{H})$. The cephalic region is dark brown with some white

386

387

388

389

390

391

392

393

394

395

396

397

398

399

400

401

402

403

404

405

406

407

408

409

410

411

412

413

414

415

416

417

418 spots with irregular dots up to the supralabial region in lateral view (Figure 7B); a loreal region with ochre patches and light brown iris with black reticles; nasolabial projections are cream; the ventrolateral surface is dark brown. Ventral surfaces are dark brown with some cream and white blotches with scattered dots; the mental and gular surfaces are uniformly dark brown or dark grey with some irregular white circular spots bordering the maxillary region. In adult males the mental gland is light brown; the palmar and plantar surfaces are always dark brown or dark grey.

\section{Discussion}

The new localities add to the known range of Bolitoglossa pandi and the detailed examination of the Supatá population allowed not only the expansion of knowledge about the distribution and natural history traits of this species but also the reassessment of its conservation status and the validation of its characters for taxonomic identification vis-a-vis its congeners. Despite efforts done by herpetologists who sought to characterize and describe the Andean amphibians in the second half of the $20^{\text {th }}$ century and the beginning of the $21^{\text {st }}$ (Ruiz-Carranza, Ardila-Robayo \& Lynch, 1996; Lynch, Ruiz-Carranza \& Ardila-Robayo,1997; Lynch 1999; Arroyo, Jerez, \& Ramírez-Pinilla, 2003; Acosta-Galvis, 2015; Acosta-Galvis et al., 2020), large areas of the western slope of the Cordillera Oriental of Colombia still lack intensive sampling. Therefore, the known distribution of $B$. pandi as well as other Andean amphibians is still fragmentary.

Since Brame \& Wake's (1963) original description of B. pandi, several characters such as dorsal surfaces color (Figure 7) have had conflicting or ambiguous diagnostic characters (Acosta-Galvis and Gutiérrez-Lamus, 2012). However, our findings increased the understanding of the morphological variability of $B$. pandi. Based on living specimens obtained in the municipalities of Guaduas, Supatá, and Villeta, we add new data to the original description (Brame and Wake, 1963) because these had not been described in life (and the holotype is poorly preserved), and evidence of a broad intrapopulation color variation was not available due to restricted sampling. Our findings allow clarification of taxonomical misidentifications in the literature. For example, Acosta-Galvis \& Rueda-Almonacid (2004), during the first threat assessment of $B$ pandi, included erroneously a picture of $B$. walkeri as the species' portrait.

Neotropical salamanders have been considered amphibians with secretive habits and low encounter rate into the Andean Forest (Brame \& Wake, 1963; Gibbons, 1983; 
419 Barrio-Amoros \& Fuentes, 1999; Acosta-Galvis \& Gutiérrez-Lamus, 2012).

420 Nevertheless, our results challenge this general assumption and provide support for 421 previous studies which related specific environmental conditions with high abundance 422 and density of Andean salamander populations (Houck, 1977; Jimenez, 1994; Salgado423 Aráuz, 2005; Cadenas et al., 2009; Ortega, Monares-Riaño \& Ramírez-Pinilla, 2009; 424 Gutiérrez-Lamus, Lynch \& Martínez-Villate, 2011; Neckel-Oliveira et al., 2011; del Río425 Gracía, Serrano-Cardozo \& Ramírez-Pinilla, 2014; Cruz, Galindo \& Bernal, 2016). 426 Bolitoglossa pandi follows the common pattern observed in upland tropical 427 salamanders, having a narrow elevational range (1700-2270 m. a.s.I), in which 428 elevation, leaf litter depth $(>6 \mathrm{~cm}$ ), vegetation layers ( $>5$ vegetation strata), and environmental mean temperature $\left(16-19{ }^{\circ} \mathrm{C}\right)$ were the main predictor variables for their presence, abundance and population density (Wake \& Lynch, 1976; Gutiérrez-Lamus, Lynch \& Martínez-Villate, 2011; Cruz, Galindo \& Bernal, 2016; Donaire et al., 2019). Likewise, observed patterns of habitat use by $B$. pandi agree with those previously reported by del Río-García, Serrano-Cardozo \& Ramírez-Pinilla(2014) in which the salamanders exhibiting both arboreal and terrestrial habits, perching on the upper side of leaves (at heights between 2.5 and $250 \mathrm{~cm}$ above the forest floor), showing a positive correlation between perch height, SVL and mass. Additionally, the highest abundance of neonates and juvenile observed during high rainy season (from mid-March through June) agrees previously observation made by these authors. However, a negative correlation or no correlation between perch height and salamander body size has been reported for $B$. paraensis and $B$. nicefori, respectively, suggesting that climatic variability or elevational range distribution could determine microhabitat use (Ortega, MonaresRiaño \& Ramírez-Pinilla, 2009; Simões-Correa \& Chagas-Rodrigues, 2017). This and many more questions concerning microhabitat use of South American Bolitoglossa salamanders remain open, highlighting the fact that the state of knowledge on their ecology and natural history still presents many gaps.

The occurrence of individuals of Bolitoglossa pandi was strongly related with habitat structure. Sampling plots in which $B$. pandi was present were positively correlated with highly structured habitats and deep leaf litter, characteristics traditionally associated with suitable habitats for amphibians because they provide food (leaf litter arthropods), shelter, nesting sites, and microclimate stability by retaining moisture through the soil interface after rainfall events (Heatwole, 1962; Jaeger, 1980; HarveyPough et al., 1987; Vitt \& Caldwell, 2001). Additionally, the leaf litter depth was significant correlated with percent vegetation cover and vegetation layers, which agrees with the pattern previously reported by de Maynadier \& Houlahan (2008) in which the composition and structure of the leaf litter and local tree canopy is significantly related in tropical forests.

Conversely, highly homogenous sampling plots in which were dominant pastures, graminoids, bare soil, and rocks, showed the lowest or no detection grade of 
459 B. pandi. Therefore, this result showed that habitat degradation due local human 460 activities such logging, and cattle ranching have direct negative effects in the quality of

461

462

463

464

465

466

467

468

469

470

471

472

473

474

475

476

477

478

479

480

481

482

483

484

485

486

487

488

489

490

491

492

493

494

495

496

497

498 leaf litter general habitat structure of $B$. pandi (Vitt \& Caldwell, 2001). The detection and high local abundance of $B$. pandi was strongly correlated with the same habitat variables associated with the detection of other Andean salamanders such as $B$. adspersa, B. altamazonica, B. nicefori, and B. orestes, and B. ramosi (Valdivieso \& Tamsitt, 1965; Wake \& Lynch, 1976; Cadenas et al., 2009; Gutiérrez-Lamus, Lynch \& Martínez-Villate, 2011; Leenders \& Watkins-Colwell, 2013; Galindo, Cruz \& Bernal, 2018). Thus, the strong dependency on a narrow environmental range of conditions makes the Andean bolitoglossines highly vulnerable to local changes by human activities affecting these habitat variables.

Usually, activity in bolitoglossines has been associated with variation in relative humidity or climatic conditions, as well as breeding season (Vial, 1968; Wake \& Lynch, 1976; Ortega, Monares-Riaño \& Ramírez-Pinilla, 2009; Simões-Correa \& ChagasRodrigues, 2017). Activity of Bolitoglossa pandi follows this general pattern but with certain deviations compared to some of its congeners. For example, the number of $B$. pandi active individuals was strongly and positively correlated with the environmental temperature, whereas it was moderately and negatively correlated with the relative humidity [versus a positive correlation between active individuals and relative humidity observed in B. mombachoensis, B. paraensis, and B. subpalmata (Vial, 1968; SalgadoAráuz, 2005; Simões-Correa \& Chagas-Rodrigues, 2017)]. This correlation was consistent across all sampling occasions, suggesting that climate variability has little influence on the activity pattern of $B$. pandi. However, future studies should be carried out to clarify which environment variables can determine the general activity pattern in the tropical Bolitoglossa species.

Niche partitioning has been reported for many populations of Nearctic and Neotropical salamander species (Jaeger \& Gergits, 1979; Wicknick, 1995; Arif, Adams, \& Wicknick, 2007; Jaeger et al,. 2016).Intraspecific niche partitioning in salamanders has been explained as a life history strategy to maximize foraging success, predator avoidance, and mating success (Jaeger \& Gergits, 1979; Holomuzki, 1986; Cloyed \& Eason, 2017). Particularly, intraspecific niche partitioning due to ontogenetic shifts or sexual microhabitat selection has been documented for some Bolitoglossa species [e.g. B. dofleini and B. nicefori (Raffaëlli, 2007; Ortega, Monares-Riaño \& Ramírez-Pinilla, 2009). Previously, del Río-García, Serrano-Cardozo \& Ramírez-Pinilla (2014) explored whether intraspecific niche partitioning due to ontogenetic shifts or sexual microhabitat selection was present in B. pandi populations at the municipality of Supatá. However, these authors did not find significant differences in microhabitat use between sexes or body size classes. However, our study showed that adults and juveniles+neonates of $B$. pandi from the Cuzcungos locality showed significant differences between the activity peaks, indicating that development stages of this species are disaggregated through the 
499

500

501

502

503

504

505

506

507

508

509

510

511

512

513

514

515

516

517

518

519

520

521

522

523

524

525

526

527

528

529

530

531

532

533

534

535

536

537

538

niche time-axis. Future experimental studies will be needed to understand how intraspecific niche time-partitioning is acting through environmental heterogeneity in the ecology and evolution of the South American bolitoglossines.

\section{Conclusions}

Bolitoglossa pandi followed expected association between habitat structure and morphological traits predicted by the general adaptive radiation pattern observed in Neotropical salamanders (Darda \& Wake, 2015). Habitats with high percent of vegetation cover and leaf litter depth provide suitable environmental conditions for this species and define the sets of predictor variables associated with occupation of $B$. pandi in the Andean forests. Given the narrow elevational range of this species, local changes of these habitat variables along small areas could lead to extirpation of their populations. We recommend conducting occupancy modelling as a tool for monitoring the detection / non-detection of $B$. pandi related with habitat loss.

Urodela is the most endangered vertebrate group on Earth being more than $54.7 \%$ of its species are thought of as "endangered" (Hernandez, 2016). Our result agrees with the general pattern observed in other salamander taxa in which habitat disturbance driven by human activities has deleterious effects on their presence or population densities given their high habitat specificity (Lips, 1998; Collins \& Storfer, 2003; Hernandez, 2016). Habitat loss continues to stand out as the main threat for $B$. pandi. This fact has significant importance in conservation issues because the Andean forest is one of the most threatened ecosystems by human activities in Colombia (Etter et al., 2018). Therefore, despite our observations of a healthy and stable salamander population that showed high population density and constant recruitment in the municipalities of Supatá, Guaduas, and Villeta, we recommend that $B$. pandi be retained as Endangered (EN) on the IUCN Red List based on the IUCN Criterion B, given its restricted extent of occurrence (ca. $2,500 \mathrm{~km}^{2}$ ), as well as the ongoing habitat loss within its range due to agriculture, cattle ranching, logging, and urban development.

Finally, Colombian herpetologists must encourage private and public research centers, universities, conservation agencies and industries to support fieldwork that seeks to increase the knowledge on amphibian diversity, filling the distribution gaps of the Andean species, particularly salamanders (Ospina-Sarria \& Angarita-Sierra, 2020). The latter are essential to develop successful conservation and management strategies and environmental regulations in a megadiverse country such as Colombia (Bury, 2006). An example is this study, wherein, we characterized several important aspects of population biology and ecology of the endangered species $B$. pandi. By filling gaps in our knowledge of this species, we were able to describe in detail the habitat requirements for its conservation and provide an update of its conservation status.

\section{Acknowledgments}

Peer) reviewing PDF | (2020:04:47555:2:0:NEW 29 Jul 2020) 
539 We thank all students of the Grupo de Investigación de Biología de Organismos

540 Tropicales (BIOTUN) of the Universidad Nacional de Colombia for their help and 541 support during the fieldwork and lab procedures. We especially thank Maria Carolina

542 Becerra (Biology department, UNAL) for her friendship and support through all this 543 study; the staff of the NGO YOLUKA for their general support; Rebeca Morantes544 Zamora for her help with the map; John D. Lynch (Instituto de Ciencias Naturales of 545 Universidad Nacional de Colombia) for his support, advice and for allowing us to use 546 the lab equipment under his care. Special thanks to Adriana Zuleta and Alejandro López 547 for giving us the support and freedom to seek salamanders at Cuzcungos Natural 548 Reserve; William Gutierrez Moreno, coordinator of the Project Management Program of 549 Universidad Nacional de Colombia for his support. We thank Kelsey Neam (IUCN SSC

550 Amphibian Specialist Group, Global Wildlife Conservation) and Thibaud Aronson 551 (Missouri Botanical Garden) for the review of the manuscript. We thank the staff of 552 Ecotropico, as well as to Rafael Enrique Martínez and family, José Adelfo Vargas and 553 family for kindly allowing us to seek amphibians and reptiles at their forest and 554 farmlands. Special thanks to all the community of the municipalities of Guaduas, 555 Supatá, Venecia, and Villeta to allow us to work together for the amphibian and reptile 556 conservation of Colombia. Finally, thanks to Axel Hernandez and the anonymous 557 reviewer for their valuable comments on this paper.

558

559

560

561

562

563

564

565

566

567

568

569

570

571

572

573

574

575

576

577

578

579

580

581

582

\section{References}

Acosta-Galvis AR, Gutiérrez-Lamus DL. 2012. A new species of salamander (Bolitoglossa: Plethodontidae) from the Cordillera Oriental of the Colombian Andes. Papéis Avulsos de Zoologia 52(18): 201-218 DOI: 10.1590/s0031-10492012001800001.

Acosta-Galvis AR, Restrepo AE. 2001. Una nueva especie de Bolitoglossa (Caudata: Plethodontidae) de las selvas del Magdalena Medio en Colombia. Caldasia 23(2):467473.

Acosta-Galvis AR, Rueda-Almonacid JV. 2004. Salamandra de Pandi Bolitoglossa pandi. In: Rueda-Almonacid JV, Lynch DL, Amezquita A, eds. Libro rojo de anfibios de Colombia. Bogotá D.C: Panamericana,206-209.

Acosta-Galvis AR. 2015. Una nueva especie del género Pristimantis (Anura: Craugastoridae) del complejo de páramos Merchán-Iguaque (Boyacá, Colombia). Biota Colombiana 16 (2): 107127.

Acosta-Galvis AR. 2020. Lista de los Anfibios de Colombia. Available at https://www.batrachia.com (accessed 21 May 2020).

Acosta-Galvis, AR, Hoyos JM. 2006. A new species of salamander (Caudata: Plethodontidae: Bolitoglossa) from the subandean forest Western Cordillera of Colombia. Herpetologica 62(3):302-308.

Akaike H. 1973. Information theory and an extension of the maximum likelihood principle. In: Petrovand BN, Caski F. Proceeding of the Second International Symposium on Information Theory. Budapest: Akademiai Kiado, 1-451.

Anderson MT, Mathis A. 2006. Diets of Two Sympatric Neotropical Salamanders, Bolitoglossa mexicana and B. rufescens, with Notes on Reproduction for B. rufescens. Journal of Herpetology 33(4):601-602 DOI:10.2307/1565576. 
583

584

585

586

587

588

589

590

591

592

593

594

595

596

597

598

599

600

601

602

603

604

605

606

607

608

609

610

611

612

613

614

615

616

617

618

619

620

621

622

623

624

625

626

627

628

629

630

Arif S, Adams DC, Wicknick JA. 2007. Bioclimatic modeling, morphology, and behavior reveal alternative mechanisms regulating the distributions of two parapatric salamander species. Evolutionary Ecology Research 9(5): 843-854.

Arroyo S, Jerez A, Ramírez-Pinilla MP. 2003. Anuros de un bosque de niebla de la Cordillera Oriental de Colombia. Caldasia. 25:153-167.

Barrio-Amorós CL, Fuentes-Ramos O. 1999. Bolitoglossa spongai a new species of salamander (Caudata: Plethodontidae) of Venezuelan Andes, with comments on the genus in Venezuela. Acta Biologica Venezuelica 19(4): 9-19.

Bingham RE, Papenfuss TJ, Lindstrand L, Wake DB. 2018. Phylogeography and Species Boundaries In the Hydromantes shastae Complex, With Description of Two New Species (Amphibia; Caudata; Plethodontidae). Bulletin of the Museum of Comparative Zoology 161(10):403-427 DOI:10.3099/mcz42.1

Bolar K. 2019. STAT: Interactive Document for Working with Basic Statistical Analysis. R package version 0.1.0.

Bourne R. 2010. ImageJ. In: Fundamentals of Digital Imaging in Medicine. London: SpringerVerlag.

Brame AH, Wake DB. 1962. A new plethodontid salamander (genus Bolitoglossa) from Venezuela with redescription of the Ecuadorian B. palmata (Werner). Copeia 1962(1): 170-177.

Brame AH, Wake DB. 1963. Contributions to the Salamanders of South America. Contributions in Science. Natural History Museum of Los Angeles County 69:1-72.

Brcko IC, Hoogmoed MS, Neckel-Oliveira S. 2013. Taxonomy and distribution of the salamander genus Bolitoglossa Duméril, Bibron \& Duméril, 1854 (Amphibia, Caudata, Plethodontidae) in Brazilian Amazonia. Zootaxa 3686(4):401-431 DOI:10.11646/zootaxa.3686.4.1

Bruce RC. 1997. Life History Attributes of the Salamander Bolitoglossa colonnea. Journal of Herpetology 31(4):592-594 DOI: 10.2307/1565618.

Bury RB. 2006. Natural history, field ecology, conservation biology and wildlife management: time to connect the dots. Herpetological Conservation and Biology 1(1):56-61.

Cadenas DA, Pérez-Sánchez AJ, Villa P, De Ascenção AA. 2009. Relative Abundance Habitat Use and Diet of Bolitoglossa orestes (Urodela: Plethodontidae) in a Venezuelan Andean Cloud Forest. ECOTRÓPICOS 22(2):99-109.

Chen M, Combs C. 2001. An alternative killing agent for amphibians. Herpetological Review 32(2):93-94.

Chevan, A, Sutherland M. 1991. Hierarchical partitioning. The American Statistician 45(2): 90-96 DOI: 10.1080/00031305.1991.10475776.

Cloyed CS, Eason PK. 2017. Niche partitioning and the role of intraspecific niche variation in structuring a guild of generalist anurans. Royal Society Open Science: 4(3): 170060 DOI:10.1098/rsos.170060.

Collins J, Storfer A. 2003. Global amphibian declines: sorting the hypotheses. Diversity and Distributions 9(2003):89-98.

Crump ML, Scott NJ. 1994. Visual encounters surveys. In: Heyer W, Donelly M, MacDiarmind R, Hayeck L, Foster M, eds. Measuring and monitoring biological diversity, standard methods for amphibians. Washington: Smithsonian Institution Press,354-352.

Cruz EX, Galindo CA, Bernal MH. 2016. Dependencia térmica de la salamandra endémica de Colombia Bolitoglossa ramosi (Caudata, Plethodontidae). Iheringia. Série Zoologia 106 DOI: 10.1590/1678-4766e2016018.

Darda DM, Wake DB. 2015. OsteologicalVariation among Extreme Morphological Forms in the Mexican Salamander Genus Chiropterotriton (Amphibia: Plethodontidae): Morphological Evolution and Homoplasy. PLoS ONE 10(6): e0127248 DOI: 10.1371/journal.pone.0127248.

Peer) reviewing PDF | (2020:04:47555:2:0:NEW 29 Jul 2020) 
631

632

633

634

635

636

637

638

639

640

641

642

643

644

645

646

647

648

649

650

651

652

653

654

655

656

657

658

659

660

661

662

663

664

665

666

667

668

669

670

671

672

673

674

675

676

677

678

de Maynadier PG, Houlahan JE. 2008. 13 Conserving Vernal Pool Amphibians in Managed Forests. In: Calhoun AJK \& deMaynadier PG, eds. Science and Conservation of Vernal Pools in Northeastern North America: Ecology and Conservation of Seasonal Wetlands in Northeastern North America. New York: CRC Press, 253-280.

del Río-García JS, Serrano-Cardozo VH, Ramírez-Pinilla MP. 2014. Diet and Microhabitat Use of Bolitoglossa cf. pandi (Caudata: Plethodontidae) from the Cordillera Oriental of Colombia. South American Journal of Herpetology 9(1):52-61 DOI: 10.2994/sajh-d-13-00031.1.

Donaire RA, Pallais, JM, Chung J, Rizo, Cobos MA, De los Santos Rosales M, Jun J, Casco-Robles MM. 2019. Constricted spatiotemporal foraging of the regenerating salamander, Bolitoglossa mombachoensis. Ecosphere10(10) DOI: 10.1002/ecs2.2897.

Durbin J, Watson GS. 1950. Testing for serial correlation in least squares regression: I. Biometrika 37(3/4): 409-428 DOI: 10.1093/biomet/37.3-4.409.

Elzinga CL, Salzer DW, Willoughby JW. 1998. Measuring and monitoring plant populations. Denver: U.S. Dept. of the Interior, Bureau of Land Management.

Etter A, Andrade Á, Saavedra K, Cortés J. 2018. Actualización de la Lista Roja de los Ecosistemas Terrestres de Colombia. In: Moreno LA, Rueda C, Andrade GI, eds. Biodiversidad 2017: Estado y tendencias de la biodiversidad continental de Colombia. Bogotá D.C: Instituto de Investigación de Recursos Biológicos Alexander von Humboldt, 19.

Fox J, Weisberg S. 2019. An R Companion to Applied Regression, Third edition. Thousand Oaks CA: Sage.

Frost DR. 2020. Amphibian Species of the World: an Online Reference. Version 6.1. Electronic Database. Available at https://amphibiansoftheworld.amnh.org/index.php (accessed 28 May 2020).

Galindo CA, Cruz EX, Bernal MH. 2018. Evaluation of the combined temperature and relative humidity preferences of the Colombian terrestrial salamander Bolitoglossa ramosi

(Amphibia: Plethodontidae). Canadian Journal of Zoology 96(11):1230-1235

DOI:10.1139/cjz-2017-0330.

Gibbons, W. 2013. Their blood runs cold: Adventures with reptiles and amphibians. University of Alabama Press.

Gross J, Ligges U. 2015. nortest: Tests for Normality. R package version 1.4.

Guisande C, Heine J, González-DaCosta J, García-Roselló E. 2014. RWizard Software. Vigo: University of Vigo.

Gutiérrez-Lamus DL, Lynch JD, Martínez-Villate GC. 2011. Population estimators and adult sex ratio for a population of Bolitoglossa altamazonica (Caudata: Plethodontidae). Basic and Applied Herpetology 25(2011):43-54 DOI: 10.11160/bah.11008.

Hanken J, Wake DB. 1982. Genetic differentiation among plethodontid salamanders (genus Bolitoglossa) in Central and South America: implications for the South American invasion. Herpetologica 32(2): 272-287.

Harvey-Pough F, Smith EM, Rhodes DH, Collazo A. 1987. The abundance of salamanders in forest stands with different histories of disturbance. Forest Ecology and Management 20(1):1-9 DOI: 10.1016/0378-1127(87)90146-0.

Heatwole H. 1962. Environmental Factors Influencing Local Distribution and Activity of the Salamander, Plethodon Cinereus. Ecology: 43(3): 460-472 DOI:10.2307/1933374.

Holomuzki JR. 1986. Predator Avoidance and Diel Patterns of Microhabitat Use by Larval Tiger Salamanders. Ecology 67(3):737-748.

Hernandez A. Etude sur les Urodèles en voie de disparition. Paris: Edilivre editions, Paris, 120.

Houck L. 1977. Reproductive biology of a Neotropical Salamander, Bolitoglossa rostrata. Copeia 1977(1):70-83.

Peer) reviewing PDF | (2020:04:47555:2:0:NEW 29 Jul 2020) 
679

680

681

682

683

684

685

686

687

688

689

690

691

692

693

694

695

696

697

698

699

700

701

702

703

704

705

706

707

708

709

710

711

712

713

714

715

716

717

718

719

720

721

722

723

724

725

726

727

Hui W, Gel YR, Gastwirth JL. 2008. Lawstat: An R package for law, public policy, and biostatistics. Journal of Statistical Software 28(3) DOI: 10.18637/jss.v028.i03.

Jaeger RG. 1980. Microhabitats of a Terrestrial Forest Salamander. Copeia 1980(2): 265-268 DOI: $10.2307 / 1444003$

Jaeger RG, Gergits WF. 1979. Intra- and interspecific communication in salamanders through chemical signals on the substrate. Animal Behaviour 27(PART 1):150-156 DOI https:10.1016/0003-3472(79)90134-9.

Jaeger RG, Gollman B, Anthony DD, Gabor CR, Kohn N. 2016. Behavioral Ecology of the Eastern Red-backed Salamander: 50 Years of Research. New York: Oxford University Press.

Jimenez CE. 1994. Utilization of Puya dasylirioides (Bromeliaceae: Pitcairnoideae) as foraging site by Bolitoglossa subpalmata (Plethodontidae: Bolitoglossini). Revista De Biologia Tropical 42(3): 703-710.

Leenders TAAM, Watkins-Colwell GJ. 2013. Morphological and behavioral adaptations in Bolitoglossa colonnea (Caudata, Plethodontidae) in relation to habitat use and daily activity cycle. Phyllomedusa: Journal of Herpetology 2(2):101-104 DOI:10.11606/issn.23169079.v2i2p101-104.

Lips. 1998. Decline of a tropical amphibian fauna. Conservation Biology 12(1):106-117.

Lynch JD, Ruiz-Carranza PM, Ardila-Robayo MC.1997. Biogeographic patterns of Colombian frogs and toads. Revista de la Academia Colombiana de Ciencias Exactas, Físicas y Naturales 21(80): 237-248.

Lynch JD, Suárez-Mayorga AM. 2002. Análisis Biogeográfico de los Anfibios Paramunos. Caldasia 24(2): 471-480.

Lynch JD. 1999. Ranas pequeñas, la geometría de evolución y la especiación en los Andes colombianos. Revista de la Academia Colombiana de Ciencias Exactas, Físicas y Naturales 23 (86): 143-159.

Lynch JD. 2001. A small amphibian fauna from a previously unexplored páramo of the Cordillera Occidental in western Colombia. Journal of Herpetology 35(2):226-231.

Mackenzie DI, Nichols JD, Hines JE, Knutson MG, Franklin AB. 2003. Estimating site occupancy, colonization, and local extinction when a species is detected imperfectly. Ecology 84(8):2200-2207.

Naimi B, Hamm Na, Groen TA, Skidmore AK, Toxopeus AG. 2014. "Where is positional uncertainty a problem for species distribution modelling." Ecography 37(2) : 191-203. DOI: 10.1111/j.1600-0587.2013.00205.x.

Nally RM, Walsh CJ. 2004. "Hierarchical partitioning public-domain software." Biodiversity and Conservation 13: 659-660 DOI: 10.1023/B:BIOC.0000009515.11717.0b.

Neckel-Oliveira S, Sarmento JFM, Galatti U, Suárez P, Lima C, Lima AA, Fáveri SB. 2011. Reproductive Traits of the Brazilian Salamander Bolitoglossa paraensis (Urodela: Plethodontidae). Copeia 2011(3):457-462 DOI: 10.1643/ce-08-219

Ortega JE, Monares-Riaño JM, Ramírez-Pinilla MP. 2009. Reproductive Activity, Diet, and Microhabitat Use in Bolitoglossa nicefori (Caudata: Plethodontidae). Journal of Herpetology 43(1):1-10 DOI: 10.1670/07-250r2.1.

Ospina-Sarria, JJ, Angarita-Sierra T. 2020. A New Species of Pristimantis (Anura: Strabomantidae) from the Eastern Slope of the Cordillera Oriental, Arauca, Colombia. Herpetologica 76(1): 83-92.

R Core Team. (2012). R: A language and environment for statistical computing. Viena: R Foundation for Statistical Computing. Retrieved from http://www.r-project.org/*

Raffaëlli, J. 2007. Les Urodèles du Monde. Condé-sur-Noireau: Penclen Édition.

Ridout M, Linkie M. 2009. "Estimating overlap of daily activity patterns from camera trap data." Journal of Agricultural, Biological, and Environmental Statistics 14(3) : 322-337 DOI:

Peer) reviewing PDF | (2020:04:47555:2:0:NEW 29 Jul 2020) 
728

729

730

731

732

733

734

735

736

737

738

739

740

741

742

743

744

745

746

747

748

749

750

751

752

753

754

755

10.1198/jabes.2009.08038.

Ruiz-Carranza PM, Ardila-Robayo MC, Lynch JD. 1996. Lista actualizada de la fauna de amphibia de Colombia. Revista de la Academia Colombiana de Ciencias Exactas, Físicas y Naturales 20 (77): 365-415.

Salgado-Aráuz H. 2005. Caracterización de la población y del hábitat de la salamandra endémica (Bolitoglossa mombachoensis) en la Reserva Natural Volcán Mombacho. Encuentro 37(73):77-86.

Simões-Correa F, Chagas-Rodriguez L. 2017. On the distribution of Neotropical climbing salamanders (Bolitoglossa paraensis) in a forest fragment of the eastern Amazon. Salamandra 53(3): 445-450.

Sokal R, Rohlf R.1981. Biometry: The principles and practice of statistics in biological research (First edition). San Francisco: W.H. Freeman.

Valdivieso D, Tamsitt JR. 1965. Reproduction in a Neotropical Salamander, Bolitoglossa adspersa (Peters). Herpetologica 21(3):228-236.

Vial JL. 1968. The Ecology of the Tropical Salamander, Bolitoglossa subpalmata, in Costa Rica. Revista de Biologia Tropical:15(1): 13-115.

Vitt LJ, Caldwell JP. 2001. The effects of logging on reptiles and amphibians of tropical forests. In: Fimbel RA, Grajal A, Robinson JG, eds. The Cutting Edge: Conserving Wildlife in Logged Tropical Forests. New York: Columbia University Press, 239-259.

Wake DB, Lynch JF. 1976. The distribution, ecology, and evolutionary history of plethodontid salamanders in tropical America. Bulletin of the Natural History Museum of Los Angeles County 25: 1-65.

Wake DB. 2017. Persistent Plethodontid Themes: Species, Phylogenies, and Biogeography. Herpetologica 73(3):242-251 DOI: 10.1655/HERPETOLOGICA-D-16-00065.1

White G, Burnham K. 1999. Program MARK: survival estimation from 594 populations of marked animals. Bird Study 4(1):S120-S139 DOI: 10.1080/00063659909477239.

Wicknick JA. 1995. Interspecific competition and territoriality between a widespread species of salamander and a species with a limited range. University of Southwestern Louisiana.

Peer) reviewing PDF | (2020:04:47555:2:0:NEW 29 Jul 2020) 


\section{Figure 1}

Distribution range of the poorly-known salamander Bolitoglossa pandi

Distribution range of the poorly known salamander Bolitoglossa pandi. New Northwestern records for the known distribution of Bolitoglossa pandi (IAvH-Am 10303-4, IAvH-Am 10305-8). Pentagon with a white square inside: La Esmeralda (municipality of Villeta), black star: Granada (municipality of Villeta), broad diamond: El Trigo (municipality of Guaduas). Sampled localities in the municipality of Supatá. Black square: San Marcos, asterisk: Cuzcungos Natural Reserve, solid pentagon: "El Alto" vereda Monterey. Sampled localities in the municipality of Venecia. Narrow diamond: Buenos Aires, invert triangle: El salto de la Chorrera, triangle: El Mirador, half-filled circles: Literature records. Background map was retrieved from the Esri open database accessing the following sources: DeLorme, USDS, NPS; USGS, NOAA. 


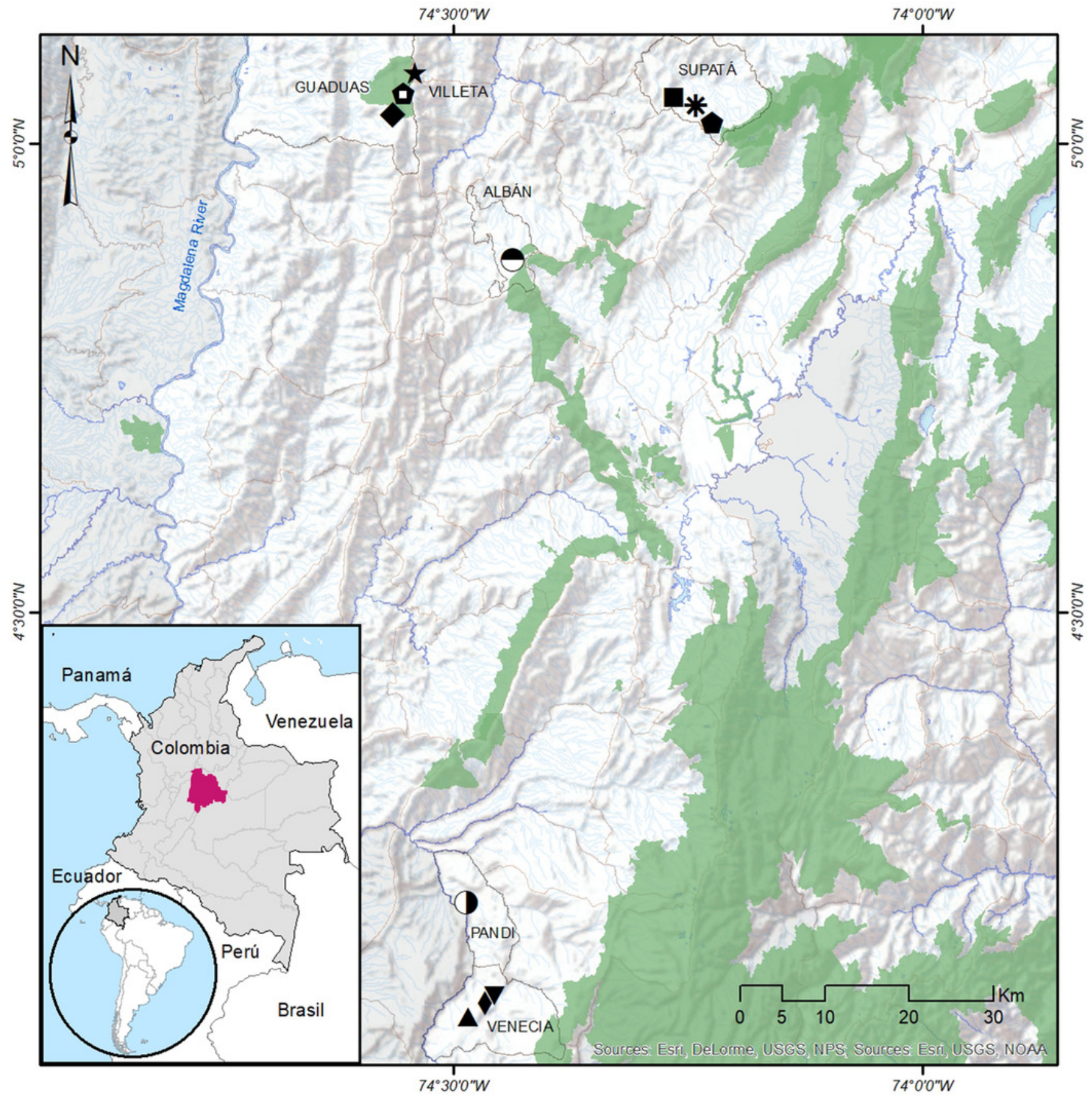

\begin{tabular}{|c|c|c|c|c|}
\hline & Literature Records & & Sampling localities & \\
\hline Department of Cundinamarca & Alban & Buenos Aires & El Alto & La Esmeralda \\
\hline Protected naturales areas & Pandi & Cuzcungos & El Mirador & San Marcos \\
\hline $\begin{array}{l}\text { Municipalities } \\
\text { Rivers } \\
\end{array}$ & & raze uningos & El Salto & \\
\hline Streams & & & & \\
\hline
\end{tabular}


Figure 2

Scatterplot depicting associations between perch high and natural history traits of $B$. pandi.

(A) Positive correlation between body length and perch high. (B) Positive correlation between weight and perch high.
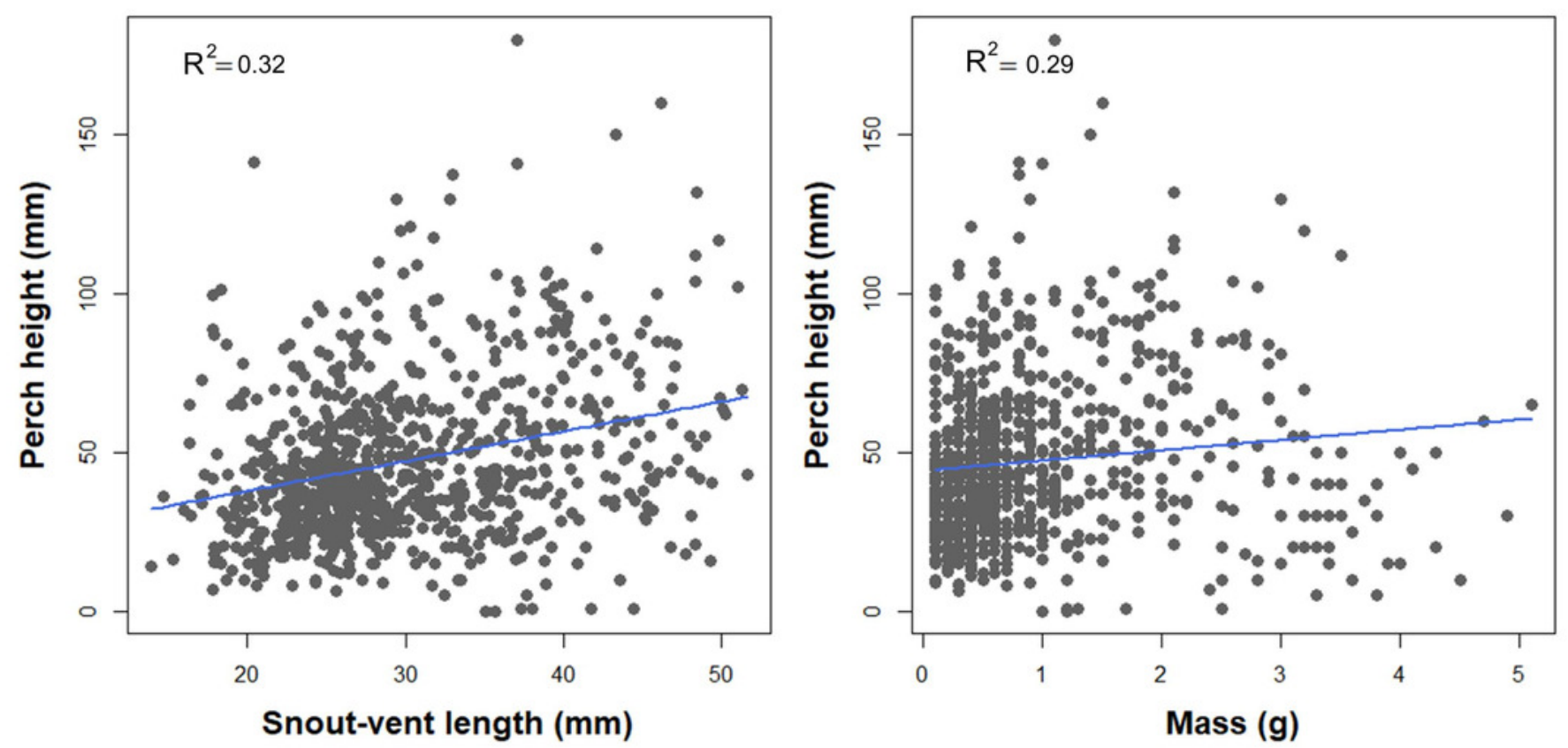


\section{Figure 3}

Habitat suitability of Bolitoglossa pandi

(A) Principal component analysis showing the observed variability in habitat structure attributes between plots with detection / non-detection of Bolitoglossa pandi. PC1 = First principal component (38.8\%). PC2 $=$ Second principal component $(23.8 \%)$. Black squares $=$ detection of Bolitoglossa pandi. Grey dots $=$ Non-detection of Bolitoglossa pandi. Inner ellipse represents 0.5 of significance; outer ellipse represents 0.95 of significance. (B) Quadratic discriminant analysis depicting the habitat variables that have greatest discrimination capacity between quadrants where Bolitoglossa pandi was detected or non-detected. Length of the vector denotes discrimination capacity of each habitat variable.
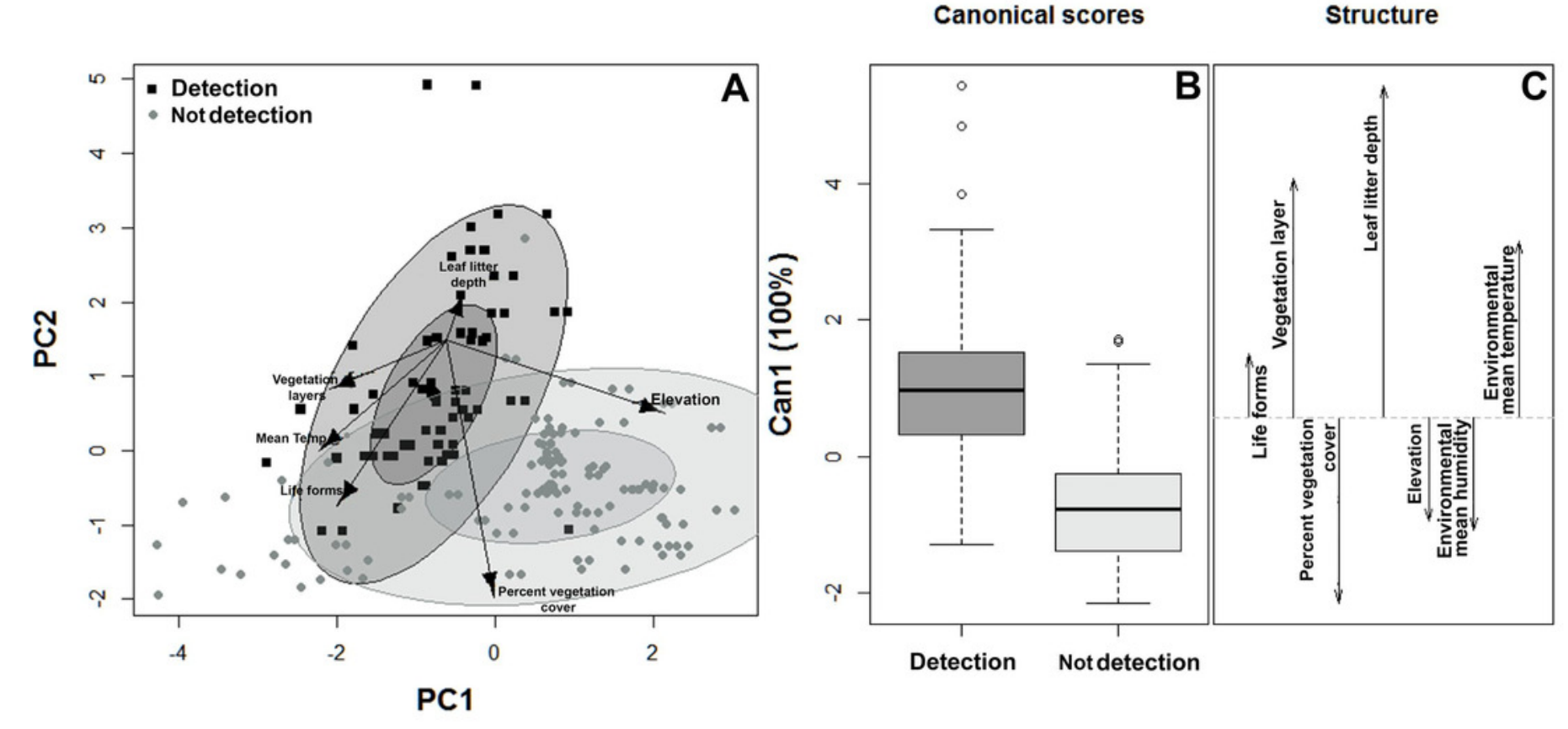

Canonical scores

Structure 


\section{Figure 4}

Circular kernel density models showing overall activity patterns of Bolitoglossa pandi

Bottom small vertical bars depicts the independent detections observed. (A) Activity pattern observed combining all sampling occasions. (B) Activity pattern observed in the first sampling occasion: low rainy season (from mid-September to mid-December 2017). Activity pattern observed in the second sampling occasion: high rainy season (from midMarch through June 2017). (D) Activity pattern observed in the third sampling occasion: low dry season (from July to mid-September 2018).

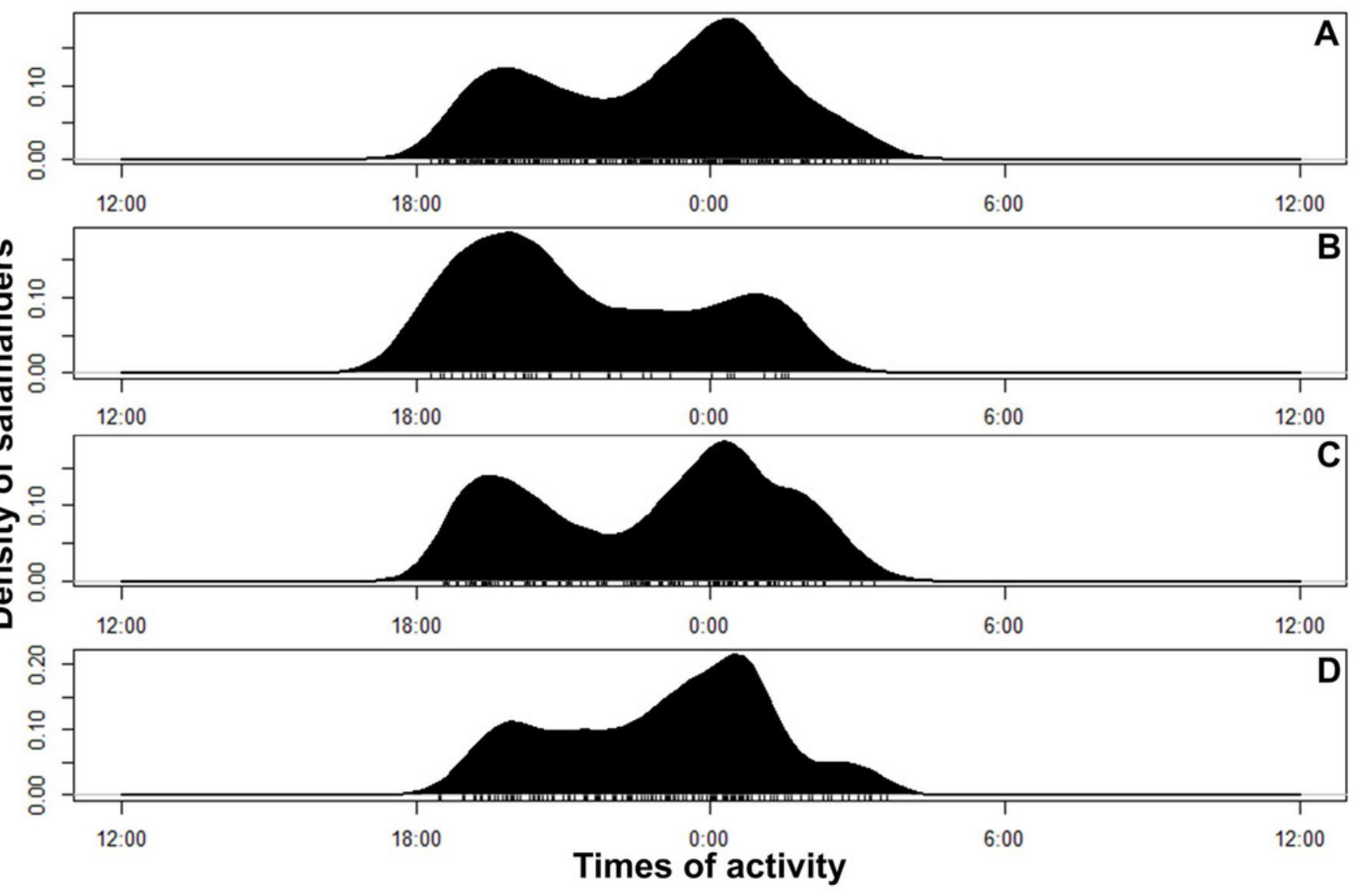


Figure 5

Abundance and body size variability during the activity period of Bolitoglossa pandi.

Activity period of Bolitoglossa pandi was divided into nine time-intervals (from $\mathrm{H} 1=$ 18:30-19:30, H2 = 19:31-20:30, H3 = ... until H9 = 02:31-03:30). (A) Nested ANOVA depicting the abundance variability among activity peaks observed. (B) Kruskal-Wallis test depicting niche partitioning between body size classes. Significant differences between timeintervals highlighting in blue.
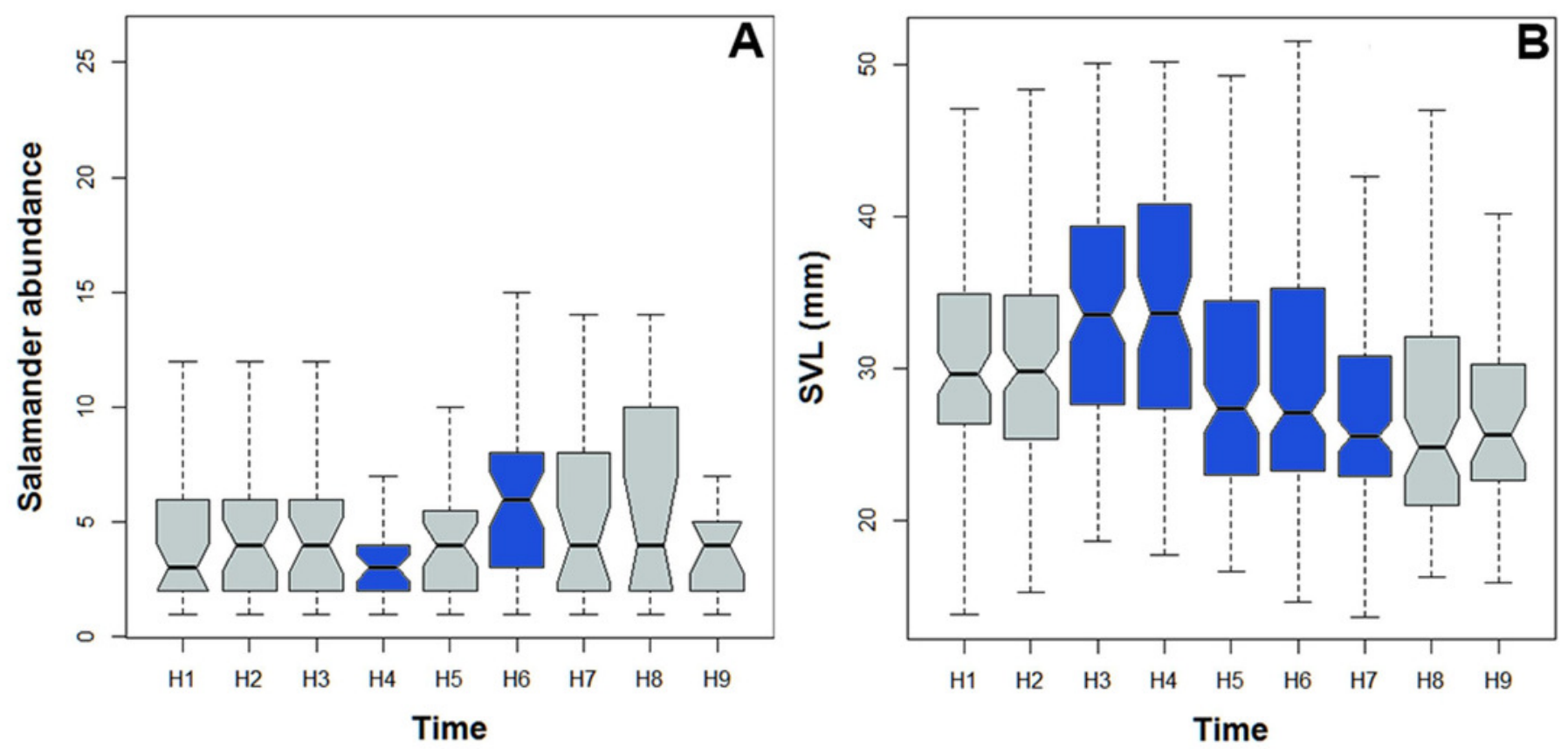
Figure 6

Population stage-structure of the Bolitoglossa pandi at the Cuzcungos locality across the sampling period.

A) First sampling occasion, September-October 2017. (B) Second sampling occasion, March 2018. (C) Third sampling occasion, July 2018. 

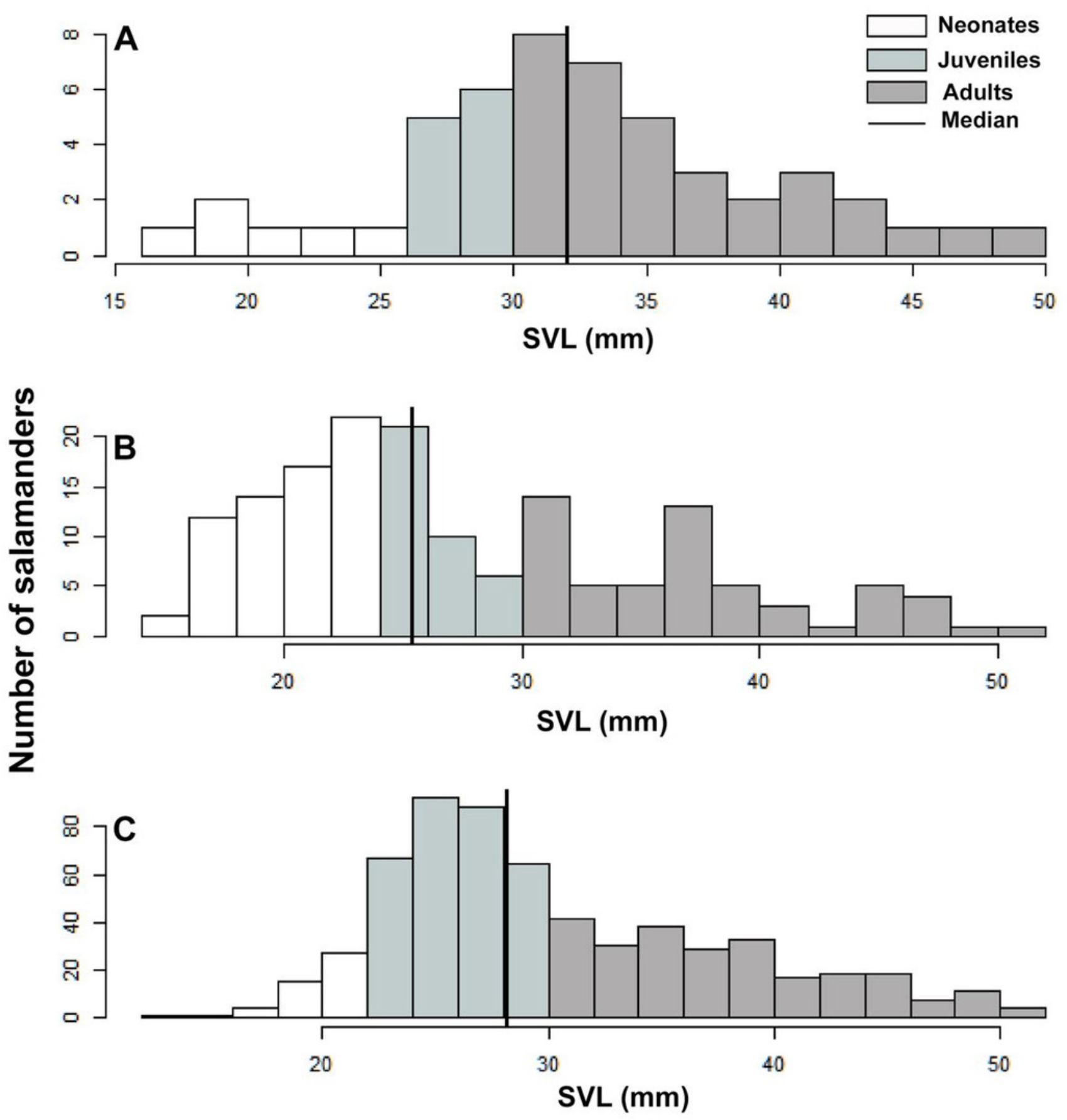


\section{Figure 7}

Color variability observed in living and preserved specimen of Bolitoglossa pandi.

(A) ventral surface of the head (ICN 45000; Pandi, Cundinamarca). (B) Lateral view of the edges lip showing the color pattern irregularly dark brown with irregular light spotting (ICN 58501, in life. Supatá, Cundinamarca). (C) ventral surfaces uniformly dark brown or dark grey with some irregular white circular spots (ICN 45000; Pandi, Cundinamarca. ICN 58502, Supatá, Cundinamarca). (D) Uniform dorsal color pattern. (E) dorsal color reddish brown that can have diffuse grey or dark blotches scarcely distinguishable to the dorsolateral. (F-H) dorsal surfaces exhibiting ochre pattern, with some diffuse irregular dark brown, yellow or cream spots. (I-J) dorsolateral surfaces diffuse band in the paravertebral region covering almost the entire dorsal surface or includes a dark brown inverted triangle shape in the interorbital region. Pictures by: Teddy Angarita-Sierra.

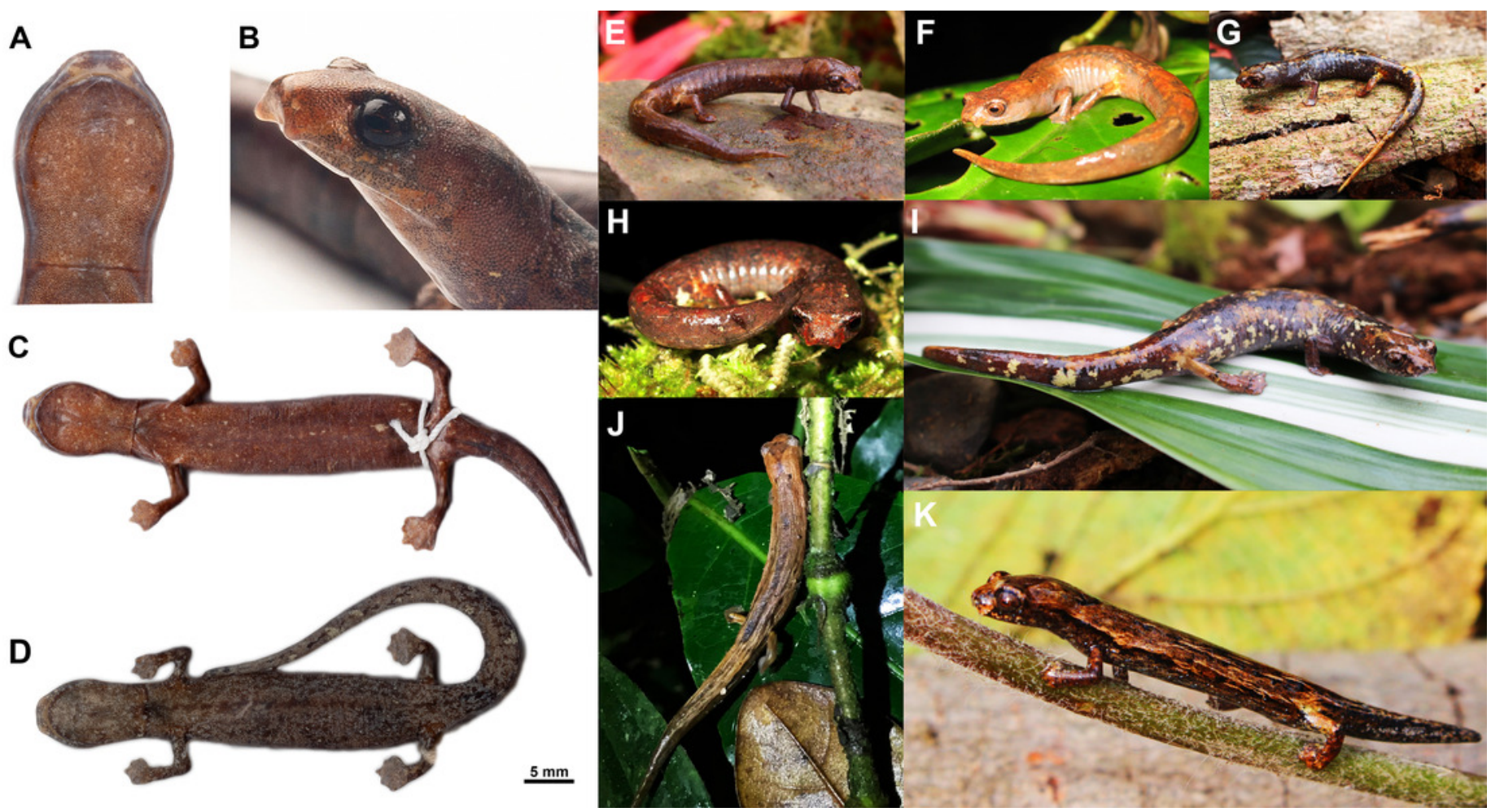




\section{Table $\mathbf{1}$ (on next page)}

Sampling localities on the Western slope of the Cordillera Oriental of Colombia.

VES: Visual encounter surveys (Crump \& Scott, 1994). P: Plots. N: Number of plots randomly selected. 


\begin{tabular}{|c|c|c|c|c|c|c|}
\hline $\begin{array}{l}\text { Municipalities } \\
\text { Vereda/locality }\end{array}$ & Latitude North & Longitude West & $\begin{array}{l}\text { Elevation }(m) \\
\text { a.s.I }\end{array}$ & $\begin{array}{l}\text { Sampling } \\
\text { protocol }\end{array}$ & $\begin{array}{l}\text { B. pandi } \\
\text { specimens } \\
\text { observed }\end{array}$ & $\begin{array}{l}\text { B. pandi } \\
\text { specimens } \\
\text { collected }\end{array}$ \\
\hline \multicolumn{7}{|l|}{ Supatá } \\
\hline $\begin{array}{l}\text { Vereda Las } \\
\text { Lajas/Monterey }\end{array}$ & $\begin{array}{l}\text { From } 5^{\circ} 2^{\prime} 18.5^{\prime \prime} \\
\text { To } 5^{\circ} 1^{\prime} 59.9^{\prime \prime}\end{array}$ & $\begin{array}{l}74^{\circ} 14^{\prime} 6.6^{\prime \prime} \\
74^{\circ} 14^{\prime} 3.5^{\prime \prime}\end{array}$ & $2119-2315$ & $P(N=45)$ & 1 & 0 \\
\hline $\begin{array}{l}\text { Vereda Las Lajas/ } \\
\text { Cuzcungos Natural } \\
\text { Reserve }\end{array}$ & $\begin{array}{l}\text { From 50 } 2^{\prime} 27.7^{\prime \prime} \\
\text { To } \quad 5^{\circ} 2^{\prime} 27.2^{\prime \prime}\end{array}$ & $\begin{array}{l}74^{\circ} 14^{\prime} 32.2^{\prime \prime} \\
74^{\circ} 14^{\prime} 27.9^{\prime \prime}\end{array}$ & 1931-2016 & $P(N=43)$ & 1391 & 12 \\
\hline Vereda San Marcos & $\begin{array}{l}\text { From } 5^{\circ} 2^{\prime} 58.9^{\prime \prime} \\
\text { To } \quad 5^{\circ} 2^{\prime} 58.3^{\prime \prime}\end{array}$ & $\begin{array}{l}74^{\circ} 15^{\prime} 53.7^{\prime \prime} \\
74^{\circ} 15^{\prime} 54.9^{\prime \prime}\end{array}$ & $1743-1773$ & $P(N=28)$ & 0 & 0 \\
\hline \multicolumn{7}{|l|}{ Villeta } \\
\hline Vereda La Esmeralda & $5^{\circ} 3^{\prime} 17.9^{\prime \prime}$ & $74^{\circ} 32^{\prime} 49.1^{\prime \prime}$ & 1996 & VES & 10 & 2 \\
\hline $\begin{array}{l}\text { Guaduas } \\
\text { Vereda Granada } \\
\text { El Trigo site }\end{array}$ & $\begin{array}{l}5^{\circ} 4^{\prime} 1.49 " \\
5^{\circ} 2^{\prime} 9.2^{\prime \prime}\end{array}$ & $\begin{array}{l}74^{\circ} 32^{\prime} 59.6 \\
74^{\circ} 33^{\prime} 48.8^{\prime \prime}\end{array}$ & $\begin{array}{l}1816 \\
1650\end{array}$ & $\begin{array}{l}\text { VES } \\
\text { VES }\end{array}$ & $\begin{array}{c}16 \\
8\end{array}$ & $\begin{array}{l}4 \\
0\end{array}$ \\
\hline \multicolumn{7}{|l|}{ Venecia } \\
\hline Vereda Buenos Aires & $\begin{array}{l}\text { From } 4^{\circ} 4^{\prime} 57.9^{\prime \prime} \\
\text { To } \quad 4^{\circ} 4^{\prime} 44.1^{\prime \prime}\end{array}$ & $\begin{array}{l}74^{\circ} 27^{\prime} 57.7^{\prime \prime} \\
74^{\circ} 27^{\prime} 33.3^{\prime \prime}\end{array}$ & $1809-2128$ & $P(N=90)$ & 0 & 0 \\
\hline $\begin{array}{l}\text { Vereda El Diamante/El } \\
\text { salto de la Chorrera } \\
\text { Vereda El Alto/ Road } \\
\text { Venecia- Cabrera }\end{array}$ & $\begin{array}{l}\text { From } 4^{\circ} 5^{\prime} 24.6^{\prime \prime} \\
\text { To } 4^{\circ} 5^{\prime} 21.0^{\prime \prime} \\
\text { From } 4^{\circ} 4^{\prime} 5.2^{\prime \prime} \\
\text { To } \quad 4^{\circ} 4^{\prime} 11.1^{\prime \prime}\end{array}$ & $\begin{array}{l}74^{\circ} 27^{\prime} 25.5^{\prime \prime} \\
74^{\circ} 27^{\prime} 33.2^{\prime \prime} \\
74^{\circ} 29^{\prime} 6.9^{\prime \prime} \\
74^{\circ} 28^{\prime} 54.8^{\prime \prime}\end{array}$ & $\begin{array}{l}1637-1735 \\
2034-2114\end{array}$ & $\begin{array}{l}P(N=36) \\
P(N=54)\end{array}$ & 0 & 0 \\
\hline
\end{tabular}




\section{Table 2 (on next page)}

Multiple correlation analysis

Upper diagonal part contains correlation coefficient estimates. Lower diagonal part contains corresponding $p$-values. Bold values denote statistical significance at the $p<0.05$ level. 


\begin{tabular}{|c|c|c|c|c|c|c|c|c|c|}
\hline Habitat structure variable & $\begin{array}{l}\text { SVL } \\
(\mathrm{mm})\end{array}$ & $\begin{array}{c}\text { TL } \\
(\mathbf{m m})\end{array}$ & $\begin{array}{c}\text { Mass } \\
\text { (g) }\end{array}$ & $\begin{array}{c}\begin{array}{c}\text { Perch } \\
\text { height } \\
(\mathrm{mm})\end{array} \\
\end{array}$ & Growth forms & $\begin{array}{c}\text { Percent } \\
\text { vegetation } \\
\text { cover }\end{array}$ & $\begin{array}{l}\text { Vegetation } \\
\text { layers }\end{array}$ & $\begin{array}{l}\text { Leaf litter } \\
\text { depth }\end{array}$ & $\begin{array}{c}\text { Elevation } \\
(\mathrm{m}) \\
\text { a.s.I } \\
\end{array}$ \\
\hline $\mathrm{SVL}(\mathrm{mm})$ & 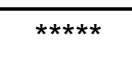 & 0.890 & 0.901 & 0.316 & 0.216 & 0.287 & 0.006 & -0.306 & -0.155 \\
\hline $\mathrm{TL}(\mathrm{mm})$ & $<0.001$ & $* * * * *$ & 0.820 & 0.281 & 0.241 & 0.262 & -0.037 & -0.306 & -0.126 \\
\hline Mass $(\mathrm{g})$ & $<0.001$ & $<0.001$ & $* * * * *$ & 0.288 & 0.194 & 0.271 & 0.018 & -0.266 & -0.134 \\
\hline Perch height (mm) & $<0.001$ & $<0.001$ & $<0.001$ & $* * * * *$ & 0.084 & 0.141 & 0.029 & -0.058 & 0.004 \\
\hline Growth forms & $<0.001$ & $<0.001$ & $<0.001$ & 0.026 & $* * * * *$ & 0.490 & -0.039 & -0.448 & -0.043 \\
\hline Percent vegetation cover & $<0.001$ & $<0.001$ & $<0.001$ & $<0.001$ & $<0.001$ & $* * * * *$ & 0.063 & -0.396 & -0.152 \\
\hline Vegetation layers & 0.883 & 0.322 & 0.627 & 0.445 & 0.300 & 0.096 & $* * * * *$ & 0.203 & 0.133 \\
\hline Leaf litter depth & $<0.001$ & $<0.001$ & $<0.001$ & 0.125 & $<0.001$ & $<0.001$ & $<0.001$ & $* * * * *$ & 0.092 \\
\hline $\begin{array}{l}\text { Elevation (m) } \\
\text { a.s.I }\end{array}$ & $<0.001$ & 0.001 & $<0.001$ & 0.906 & 0.260 & $<0.001$ & $<0.001$ & 0.015 & $* * * * *$ \\
\hline
\end{tabular}

1 


\section{Table 3(on next page)}

Principal component correlation matrix

Upper diagonal part contains correlation coefficient estimates. Lower diagonal part contains corresponding $p$-values. Bold values denote statistical significance at the $p<0.05$ level. KMO: Kaiser-Meyer-Olkin test. BST: Kaiser-Meyer-Olkin test. 


\begin{tabular}{|c|c|c|c|c|c|c|c|c|}
\hline $\begin{array}{l}\text { Habitat structure } \\
\text { variables }\end{array}$ & $\begin{array}{l}\text { Growth } \\
\text { forms }\end{array}$ & $\begin{array}{c}\text { Vegetation } \\
\text { Layer }\end{array}$ & $\begin{array}{c}\text { Percent } \\
\text { vegetation } \\
\text { cover }\end{array}$ & $\begin{array}{l}\text { Leaf } \\
\text { litter } \\
\text { depth }\end{array}$ & $\begin{array}{l}\text { Elevation } \\
\text { (m) a.s.I }\end{array}$ & $\begin{array}{l}\text { Environmental } \\
\text { mean temp }{ }^{\circ} \mathrm{C}\end{array}$ & KMO & BST \\
\hline Growth forms & $\star * * \star * \star$ & 0.481 & 0.263 & 0.002 & -0.384 & 0.368 & \multirow{6}{*}{0.6} & \multirow{6}{*}{$<0.001$} \\
\hline Vegetation layers & $<0.001$ & $* * * * *$ & -0.078 & 0.340 & -0.364 & 0.410 & & \\
\hline $\begin{array}{l}\text { Percent vegetation } \\
\text { cover }\end{array}$ & $<0.001$ & 0.285 & $* * * * *$ & -0.274 & 0.045 & -0.061 & & \\
\hline Leaf litter depth & 0.979 & $<0.001$ & $<0.001$ & 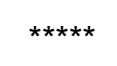 & 0.149 & 0.060 & & \\
\hline $\begin{array}{l}\text { Elevation }(\mathrm{m}) \\
\text { a.s.l }\end{array}$ & $<0.001$ & $<0.001$ & 0.541 & 0.040 & $* * * * *$ & -0.629 & & \\
\hline $\begin{array}{l}\text { Environmental mean } \\
\text { temp }{ }^{\circ} \mathrm{C}\end{array}$ & $<0.001$ & $<0.001$ & 0.401 & 0.409 & $<0.001$ & $* * * * *$ & & \\
\hline
\end{tabular}




\section{Table 4 (on next page)}

Multiple regression models

Akaike Information Criterion (AIC) employed to select the 'best model' that relates the fluctuation in habitat structure variables and the abundance of Bolitoglossa pandi. Dependent variable: Ln-transformed abundance of $B$. pandi (Lnn). Independent variables: Per.veg.cov $=$ Percent vegetation cover. Ln-transformedMean Temp $=$ Environmental mean temperature. $\mathrm{LnMeanH}=\mathrm{Ln}$-transformed relative humidity. Lnlife forms $=$ Ln-transformed number of vegetation life form. Veg.leyers = Vegetation layers. Lnleaf litter= leaf litter depth. Nor.test $=$ Kolmogorov-Smirnov's test for normality, Hom.test $=$ Breusch-Pagan test for homoscedasticity, and Aut.test = Durbin-Watson test for autocorrelation. Values shown are standard error (SE) and $t$ test-value. Bold values denote statistical significance at the $p<$ 0.05 level. 


\begin{tabular}{|c|c|c|c|c|c|}
\hline Multiple regression models & AIC & $\triangle \mathbf{A I C}$ & Nor.test & Hom.test & DW \\
\hline Lnn Lnleaf.litter+LnMean.temp+Per.veg.cov+Elevation & -73.64 & 0.0 & & & \\
\hline Lnn Lnleaf.litter+LnMean.temp+Per.veg.cov+Elevation+LnGrowth.forms & -73.08 & -0.56 & & & \\
\hline Lnn Lnleaf.litter+LnMean.temp+Per.veg.cov+Elevation +LnMean.Hr & -71.92 & -1.72 & 0.45 & 0.06 & 1.10 \\
\hline Lnn Lnleaf.litter+LnMean.temp+Veg.leyers+ & -70.04 & -3.60 & & & \\
\hline The "best" multiple regression model & $\begin{array}{l}\text { ance for } \\
\text { dance }\end{array}$ & Estimate & SE & $t$-value & $P(>|t|)$ \\
\hline \multicolumn{2}{|l|}{ Intercept } & 3.33 & 1.93 & 2.79 & 0.006 \\
\hline Ln leaf litter & $64 \%$ & 0.88 & 0.071 & 12.34 & $<0.001$ \\
\hline Ln Mean temp & $18.5 \%$ & 0.69 & 0.167 & 4.12 & $<0.001$ \\
\hline Percent vegetation cover & $12 \%$ & -1.87 & 0.50 & -3.73 & $<0.001$ \\
\hline Elevation (m) a.s.I. & & -0.001 & 0.0004 & -2.46 & 0.014 \\
\hline \multicolumn{6}{|l|}{$F=69.18, d f=4-182, P<0.0001$} \\
\hline
\end{tabular}

1 


\section{Table 5 (on next page)}

Nested ANOVA results

Standard error (SE). Bold values denote statistical significance at the $p<0.05$ level. 


\begin{tabular}{|c|c|c|c|c|c|c|c|c|c|}
\hline Time interval & $\begin{array}{l}\text { Total } \\
\text { salamanders } \\
\text { observed } \\
\text { across the } \\
\text { study }\end{array}$ & $\begin{array}{l}\text { Mean of } \\
\text { salamanders } \\
\text { observed per } \\
\text { night sampled }\end{array}$ & $\begin{array}{l}\text { Range of } \\
\text { salamanders } \\
\text { observed per night } \\
\text { sampled }\end{array}$ & Estimate & SE & $t$ value & $P(>|t|)$ & $\begin{array}{l}\text { Normality } \\
\text { test }\end{array}$ & $\begin{array}{l}\text { Levene } \\
\text { test }\end{array}$ \\
\hline $\begin{array}{c}\text { H1 } \\
(18: 30 \text { a 19:30) }\end{array}$ & 154 & 4.16 & $1-16$ & -0.0257 & 0.0234 & -1.085 & 0.279 & & \\
\hline $\begin{array}{c}\text { H2 } \\
(19: 31 \text { a } 20: 30)\end{array}$ & 172 & 4.91 & $1-20$ & 0.010 & 0.022 & 0.461 & 0.645 & & \\
\hline $\begin{array}{c}\text { H3 } \\
(20: 31 \text { a21:30) }\end{array}$ & 123 & 4.73 & $1-12$ & 0.013 & 0.023 & 0.525 & 0.599 & & \\
\hline $\begin{array}{c}\text { H4 } \\
(21: 31 \text { a } 22: 30)\end{array}$ & 97 & 3.46 & $1-8$ & -0.047 & 0.023 & -2.037 & 0.042 & & \\
\hline $\begin{array}{c}\text { H5 } \\
(22: 31 \text { a } 23: 30)\end{array}$ & 158 & 4.39 & $1-16$ & -0.006 & 0.020 & -0.309 & 0.757 & $P=0.08$ & $P=0.2$ \\
\hline $\begin{array}{c}\text { H6 } \\
(23: 31 \text { a } 00: 30)\end{array}$ & 260 & 6.05 & $1-20$ & 0.049 & 0.020 & 2.493 & 0.013 & & \\
\hline $\begin{array}{c}H 7 \\
(00: 31 \text { a } 01: 30)\end{array}$ & 196 & 4.73 & $1-18$ & 0.040 & 0.022 & 1.834 & 0.067 & & \\
\hline $\begin{array}{c}\text { H8 } \\
(01: 31 \text { a 02:30) }\end{array}$ & 116 & 6.47 & $1-26$ & 0.003 & 0.030 & 0.100 & 0.920 & & \\
\hline $\begin{array}{c}\text { H9 } \\
(02: 31 \text { a } 03: 30)\end{array}$ & 62 & 4.43 & $1-26$ & 0.003 & 0.030 & 0.100 & 0.920 & & \\
\hline
\end{tabular}


Table 6(on next page)

Wilcoxon test results

$\mathrm{N}=$ number of salamanders observed. Bold values denote statistical significance at the $\mathrm{p}<$ 0.05 level. 


\begin{tabular}{lcccccc}
\hline $\begin{array}{l}\text { Sampling } \\
\text { occasion }\end{array}$ & Occasion 1 & Occasion 2 & Median & Neonates & Juveniles & Adults \\
\hline Occasion 1 & - & - & 32.05 & $\mathrm{~N}=4(8 \%)$ & $\mathrm{N}=13(26 \%)$ & $\mathrm{N}=33(66 \%)$ \\
Occasion 2 & $\begin{array}{l}\mathrm{W}=11825 \\
\mathrm{P}<\mathbf{0 . 0 0 1}\end{array}$ & - & 25.40 & $\mathrm{~N}=55(34 \%)$ & $\mathrm{N}=49(30 \%)$ & $\mathrm{N}=57(36 \%)$ \\
Occasion 3 & $\mathrm{W}=22590$ & $\mathrm{~W}=84198$ & 28.20 & $\mathrm{~N}=76(13 \%)$ & $\mathrm{N}=277(46 \%)$ & $\mathrm{N}=252(42 \%)$ \\
\hline
\end{tabular}

1 